\title{
GEOLOGICAL SETTING AND INTRUSION TECTONICS OF THE KOTALAHTI NICKEL-COPPER DEPOSIT, FINLAND
}

\author{
GABOR GAÁL
}

\begin{abstract}
GAÁL, GABOR 1980: Geological setting and intrusion tectonics of the Kotalahti nickel-copper deposit, Finland. Bull. Geol. Soc. Finland $52,101-128$.

The wall rocks of the nickel bearing mafic and ultramafic plutonic rocks of Kotalahti are Archean banded granitoidic gneisses containing inliers of Archean metasediments and metavolcanics. The zircon ages of the granitoidic gneisses are around $2800 \mathrm{Ma}$. The zircons of the mafic plutonic rocks of the Kotalahti deposit have been dated $1883 \pm 6 \mathrm{Ma}$. The Archean rocks are exposed in the oval-shaped Valkeinen brachyantiform, surrounded by veined mica gneisses of probable Proterozoic age.

Five deformation phases have been distinguished by structural analysis. Deformation of the first phase took place during Archean times. The timing of the second deformation phase is uncertain but for the third deformation phase a Proterozoic age has been established. During the first two phases granitoidic rocks with supracrustal inliers and amphibolitic dikes were transformed into banded gneisses by strong deformation. The third deformation phase refolded these rocks into NNW trending synforms and antiforms, which were simultaneously intruded by the mafic and ultramafic plutonic rocks. The subvertical axial planes of the $\mathrm{F}_{3}$ folds were refolded into $\mathrm{S}$ shapes during the fourth deformation phase in a NW-SE trending left-lateral ductile-shear belt. This shear belt is regarded as the upper part of a deep-seated fault, along which the nickel bearing magma ascended from the upper mantle. Narrow NE-ENE trending deformation zones crossing the shear belt are interpreted to belong to the fifth deformation phase.

The largest occurrence of mafic and ultramafic plutonic rocks in the vicinity of Kotalahti is the dome-shaped massif of the Valkiajärvi gabbro in the core of the Valkeinen brachyantiform. $\mathrm{Ni}, \mathrm{Cu}, \mathrm{S}, \mathrm{TiO}_{2}$ and $\mathrm{P}$ contents of the Valkeajärvi gabbro are different from those of the mafic to ultramafic plutonic rocks of Kotalahti.
\end{abstract}

Gabor Gaál, Department of Geology, University of Helsinki, P.O. Box 115, SF-00171 Helsinki 17, Finland.

\section{Introduction}

The Kotalahti nickel-copper sulfide deposit is located in Central Finland south of the town of Kuopio in the commune of Leppävirta. The geology of the deposit and its economic features have been described by Haapala (1969), Papunen (1970), Isokangas (1978) and Papunen and Koskinen (1978). The broad geological context has been dealt with by Gaál (1972), Kahma (1973), Gaál et al. (1978), Papunen et al. (1979) and Tontti et al. (1979). The Kotalahti deposit is the economically most significant mine of the Kotalahti nickel belt, a $10-40 \mathrm{~km}$ broad and $420 \mathrm{~km}$ long metallogenic zone stretching across the southern part of Finland in NW-SE direction (Fig. 1). The tectonics of this belt are 
characterized by a NW-SE striking system of faults and fractures which have been interpreted by the author as predominantly transcurrent faults (Gaál and Rauhamäki, 1971; Gaál, 1972). Several other models have also been put forward for the explanation of the complicated fault patterns namely by Talvitie (1971, 1975), Tuominen et al. (1973) and Parkkinen (1975).

The present study was initiated by the Outokumpu Oy Exploration in 1968 with the aim of gathering information on the geological setting of the deposit, with special regard on the stratigraphy and tectonics. Since the area is well exposed detailed geological mapping to scales $1: 2000$ and $1: 4000$ have been carried out by the author in the close vicinity of the mine in an area measuring $16 \mathrm{~km}^{2}$. Altogether 1200 exposures were recorded in the years 1968 and 1969 and additional information was gained from cores of the exploration drill holes (Fig. 2). For mapping technics the ADP-system GEOKU has been applied and all data have been processed by computer (Gaál and Suokonautio, 1973). The preliminary results of this work were summarized in a company report, which contains a short description on the geology and 46 maps (Gaál, 1970).

Investigations of the Kotalahti region continued after the completion of the detailed mapping. Outokumpu Oy, Exploration enlarged the mapping area and the Kotalahti nickel belt between Varkaus and south of Kuopio has been mapped to scales $1: 10.000$ and $1: 20.000$. Results of these works are compiled in a company report by J. Parkkinen, 1974. Exploration of the area is still going on and new data are continually gathered. Therefore, although collected data cover a much larger area, it seems to be reasonable to restrict the content of this paper to the Kotalahti area. One reason for that is the hope, that a deeper knowledge of the geology, especially structures, stratig-

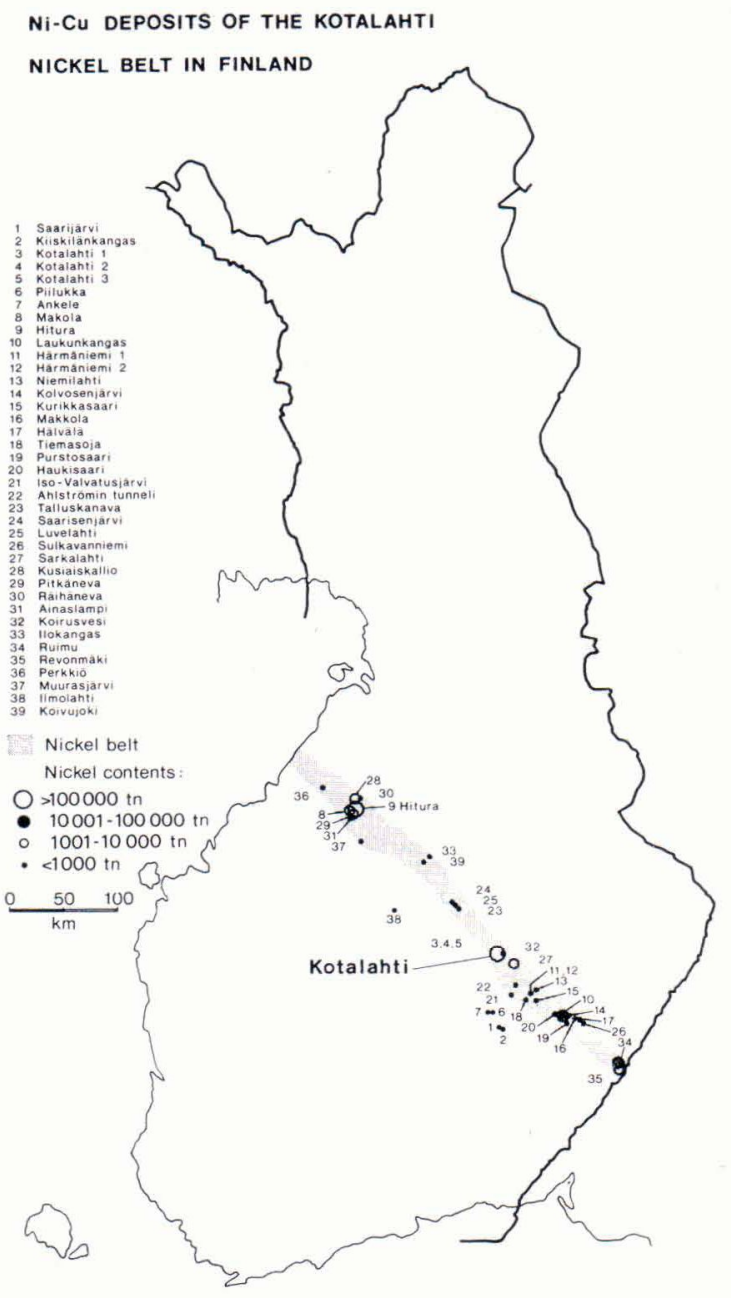

Fig. 1. Map of Finland showing location of the Kotalahti nickel belt and the Kotalahti nickelcopper deposit. Data from the Ore Deposit Data File of the Geological Survey of Finland (Tontti et al., 1979).

raphy and intrusion mechanism, may still lead to new ore findings in the immediate surroundings of the mine.

\section{Geological setting}

The Kotalahti area is built up by gneisses, schists and plutonic rocks, metamorphosed and migmatized under the conditions of the 




Exposures of the bedrock

or Exploration-drilling site

Fig. 2. Exposures and exploration drilling sites of the Kotalahti area.

upper amphibolite facies. The geological map is governed by an oval-shaped structure, the Valkeinen brachyantiform (Figs. 3 and 4). Inside this structure granite gneisses are exposed. The granite gneiss complex is surrounded by a few ten meters to 150 meters thick sequence of metasediments and metavolcanics, the epicontinental group. The epicontinental group is surrounded by banded leucocratic gneisses which, apart from the scarcity of potassium feldspar, greatly resemble the granite gneisses. The leucocratic gneisses turn into migmatized banded hornblende gneisses, which are surrounded by monotonous veined mica gneisses. The granite gneiss complex, the epicontinental group, the leucocratic gneisses and the banded hornblende gneisses are intruded by numerous 


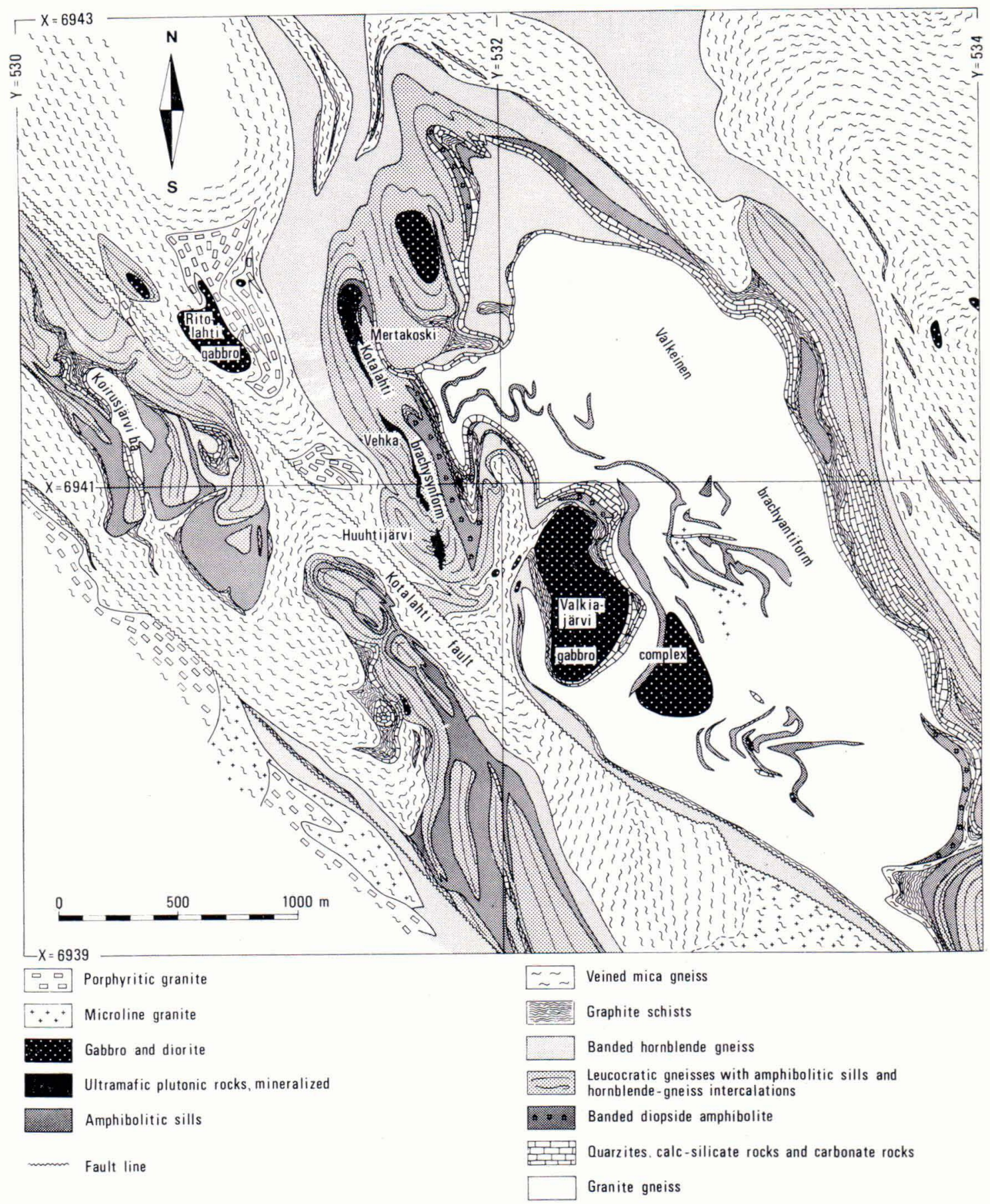

Fig. 3. Geological map of the Kotalahti area. 


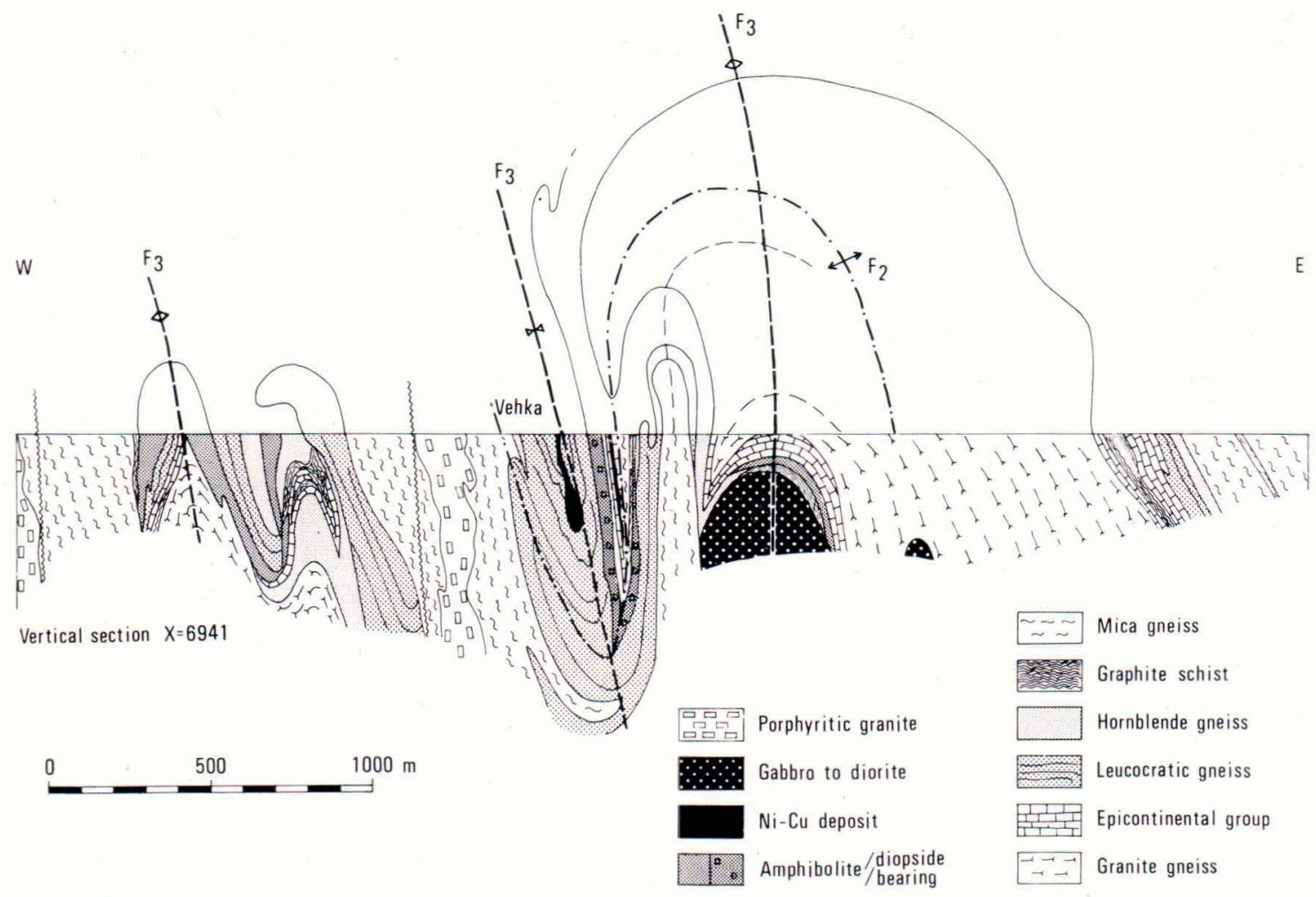

Fig. 4. Geological vertical section of the Kotalahti area with location $\mathrm{x}=6941$ on Fig. 3 .

amphibolitic dikes which are gabbroic to quartz dioritic in composition. The amphibolitic dikes have been nowhere observed to intrude the mica gneisses.

The mafic to ultramafic plutonic rocks of the Kotalahti area intrude all previously mentioned rocks, including the mica gneisses. The youngest intrusive rocks of the area are of granitic composition. Pegmatitic veins, with preferred NS-strike and subvertical dip, are met with throughout the area and the SWpart of the area is intruded by younger porphyritic granites.

\section{Stratigraphy and rocks}

Granite gneiss complex

The granite gneiss complex consists chiefly of strongly foliated, banded and migmatized pink-gray granite gneisses. The same rock type is the main component of the granitoidic part of the Archean basement complex of eastern and northern Finland as well as the Kuopio gneiss domes (Wilkman, 1938, p. 1617 and Preston, 1954).

The composition of the granite gneiss is granitic to trodhjemitic. The major minerals are in order of decreasing abundance oligoclase, microcline, quartz, biotite and in some samples, hornblende. Minor and accessoric components are muscovite, chlorite, apatite, zircon and opaques. Under the microscope the texture is granoblastic and massive to strongly foliated. Cataclastic deformation is common and in such cases potassium feldspar is underformed, which indicates secondary granitization. A few samples are devoid of potassium feldspar and cannot be petrographically distinguished from the leucocratic gneisses. 
In the central part of the Valkeinen brachyantiform microcline granite has been met with in areas of a few hundred square meters,

The granite gneisses are granitoidic intrusive rocks, in which strong deformation produced banding. They intruded the metasedimentary rocks of the epicontinental group, which are met with in the granite gneiss complex as inliers and inclusions. The largest inlier is an orthoquartzite $2-10$ meters thick and 300 meters long within the granite gneiss (Fig. 3). This quartizite is entirely recrystallized, strongly foliated and of glassy appearence. It is granitized by the leucocratic granite, similarly to the granitized quartzite of the Puijo-hill, Kuopio (Härme, 1959). Smaller inclusions of orthoquartzites have been found in the localities $\mathrm{x}=6939.78, \mathrm{y}=$ 533.13 and $\mathrm{x}=6940.08, \mathrm{y}=533.075$. Inclusions of diopside amphibolite have been met with among others at $\mathrm{x}=6941.125, \mathrm{y}=$ 532.335 and $\mathrm{x}=6941.31, \mathrm{y}=532.085$. One inclusion of mica gneiss has been found at $\mathrm{x}=6940.89, \mathrm{y}=532.875$.

A strongly altered and deformed diorite of $200 \mathrm{~m} \times 250 \mathrm{~m}$ areal size was mapped in the granite gneiss complex. Contact relations with the granite gneiss are unclear.

Both granite gneiss and diorite are intruded by numerous amphibolitic dikes. The amphibolites are composed of green hornblende and oligoclase as major components. Biotite and quartz are minor components and accessories are chlorite, apatite, zircon epidote and opaques. The amphibolites have intruded the already strongly deformed banded granite gneisses, but they are themselves foliated and cofolded with the wall rocks. They are intruded and migmatized by leucocratic trodhjemite composed of oligoclase and quartz, forming on many places typical agmatite structures (Fig. 5). The amphibolites are identical with the amphibolites of the Kuopio gneiss domes described by Preston (1954, p. 15-16). The youngest rocks of the granite gneiss complex are fine-grained crosscutting dioritic dikes striking NE-SW north of the Valkiajärvi gabbro. They are probably comagmatic with the Valkiajärvi gabbro massif.

Epicontinental group

The rocks of the epicontinental group have been studied recently in detail by Niskanen (1980) and the following description is based chiefly on his results.

The epicontinental group consists of quartzites, carbonate- and calc-silicate rocks, graphite schists and diopside amphibolites. No stratigraphic sequence can be established within the group.

The quartzites are completely recrystallized glassy and granoblastic rocks without any primary clastic texture. Four types have been distinguished: muscovite-bearing orthoquartzite, muscovite-sillimanite quartzite, feldspar-bearing quartzite and calc-silicate quartzite. The mutual order of these types is unclear, but it is assumed that the calcsilicate quartzites represent the upper part of the sequence, formed before the commencement of carbonate sedimentation. The glassy appearence of the quartzite has awakened doubts with regard to their sedimentary origin. The heavy fraction of the quartzites, however, contains detrital zircon which strongly speaks for sedimentary origin. Also the mineral composition, among others sillimanite and muscovite content, indicates impurities in primary quartzites.

The calc-silicate rocks are probably metamorphosed calc-arenites which recrystallized under amphibolite facies conditions to coarse grained skarn rocks. The major minerals are diopside, tremolite, andesine, potassium feldspar and epidote. The potassium feldspar occurs as unaltered grains replacing plagioclase. Several types of calc-silicate 


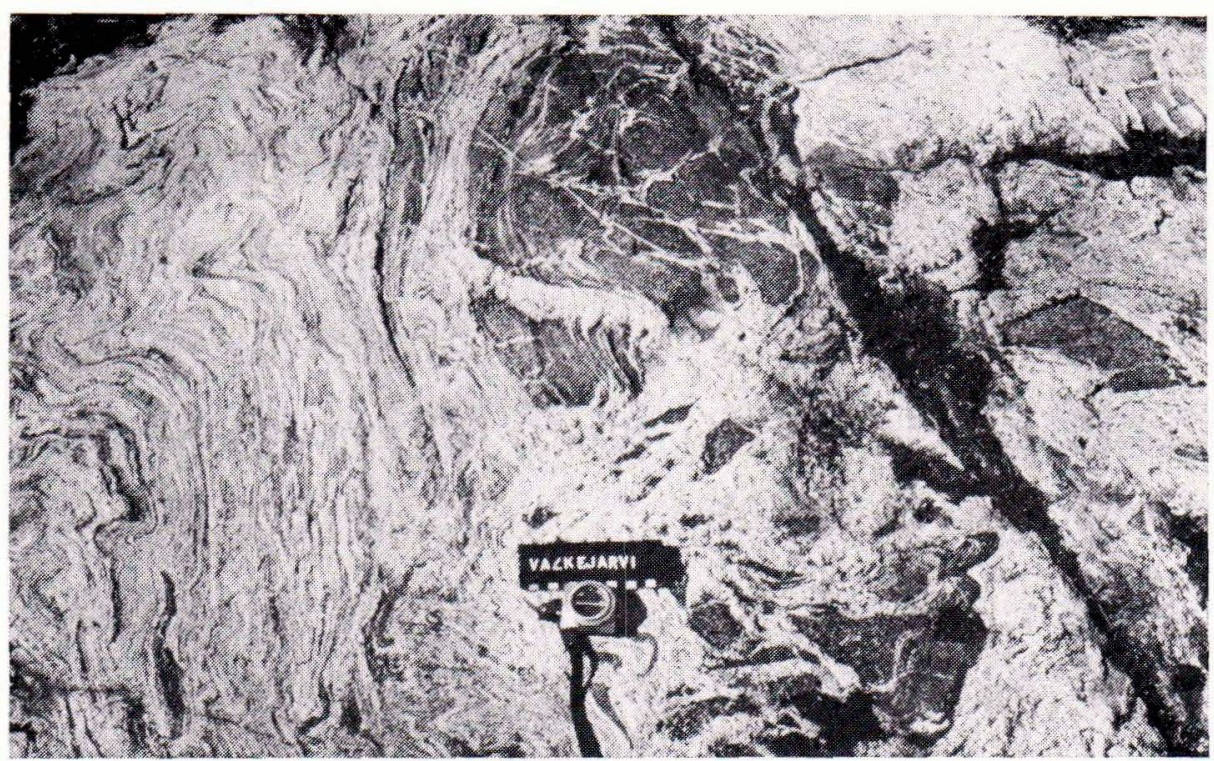

Fig. 5. Banded granite gneiss with deformed agmatite structure. Valkeinen hill.

rocks have been recognized, for example diopside skarn and a tremolite-garnetepidote-clinozoisite rock. Within calc-silicate rocks layers of carbonate rocks a few centimeters to several meters thick have been observed. The carbonate mineral is calcite, only in one sample has dolomite been met with, forming a granoblastic matrix in which sporadically serpentinized olivine and humite grains occur.

Three types of graphite schist have been recognized: biotite-chlorite-graphite schist, epidote-chlorite-graphite schist, epidotetremolite graphite schist.

The diopside-amphibolites are amphibolites with long continuous diopside bands of several millimeters to several centimeters thick. The major minerals are hornblende, diopside, plagioclase and quartz. The plagioclase is oscillatorily zoned and its composition is labradoritic. Accessoric minerals are carbonate, sphene, apatite and opaques. The average chemical composition of the diopside amphibolites is shown in Table 1.13 diopside amphibolites, 8 from the mine and 5 from its surroundings, are plotted on the AFM- diagram in Fig. 6. All the dots, except one, fall into the tholeiitic field (Irvine and Baragar, 1971). The chemical composition, before all the high iron and titanium contents, favor the volcanic origin of these rocks. Since similar banded diopside amphibolites are associated with basaltic pillow lavas in the Haukivesi area (Gaál and Rauhamäki, 1972) and in the Kuopio region, it is plausible to assume that they are volcanogenic rocks with the composition of tholeiitic basalt. Ehlers (1977) has shown by strain analysis of basaltic lavas of the Aland archipelago, that

Table 1 . The average chemical composition of the diopside amphibolites of the Kotalahti area, 13 samples, arithmetic means and the errors of arithmetic means, XRF-analyses by the Geological Laboratory of Outokumpu Oy, after Niskanen (1980).

$\begin{array}{lc}\mathrm{SiO}_{2} & 53.2 \pm 1.2 \\ \mathrm{TiO}_{2} & 1.33 \pm 0.09 \\ \mathrm{Al}_{2} \mathrm{O}_{3} & 14.7 \pm 0.7 \\ \mathrm{Fe}_{2} \mathrm{O}_{3} & \mathrm{FeO} \\ \mathrm{FnO} & 11.5 \pm 0.6 \\ \mathrm{MgO} & 0.18 \pm 0.01 \\ \mathrm{CaO} & 5.8 \pm 0.5 \\ \mathrm{Na} & 8.7 \pm 1.0 \\ \mathrm{~K}_{2} \mathrm{O} & 2.4 \pm 0.3 \\ \mathrm{P}_{2} \mathrm{O}_{5} & 1.22 \pm 0.18 \\ & 0.40 \pm 0.03\end{array}$




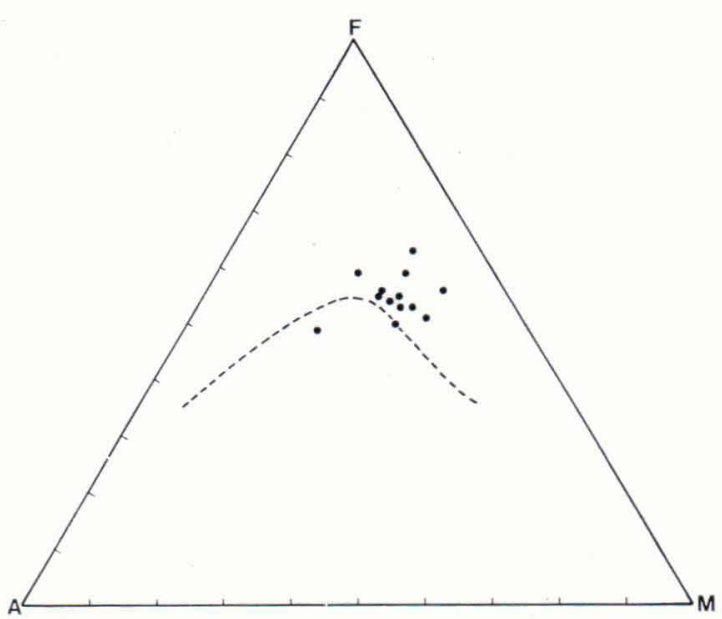

Fig. 6. Diopside-amphibolites of the Kotalahti area on the AFM-diagram $\left(\mathrm{A}=\mathrm{Na} 2 \mathrm{O}+\mathrm{K}_{2} \mathrm{O}, \mathrm{F}=\right.$ tot. $\mathrm{Fe}, \mathrm{M}=\mathrm{MgO}), 13$ analyses, after Niskanen (1980).

banded diopside amphibolite developes out of pillow lavas as a result of strong deformation.

Leucocratic gneiss and layered hornblende gneiss

The leucocratic gneiss is a light mediumto fine-grained foliated and sometimes banded rock. The fine-grained variety has been mapped as leptite. The texture is granoblastic with frequent cataclastic deformation. The main minerals are, in decreasing order of abundance, oligoclase, quartz and a brown biotite. Microcline and hornblende have been met with occasionally as major minerals. The oligoclase is sericitized in half of the 22 thin sections studied and the biotite is altered into chlorite in a third of the thin sections. The minor components are chlorite, sericite, muscovite, epidote and potassium feldspar, the accessoric minerals being opaques, apatite, zircon, sphene, carbonate and garnet.

The leucocratic gneisses contain innumerable amphibolitic dikes, of which only the extensive ones could be drawn on the geologi- cal map (Fig. 3). In the close vicinity of the ore deposit the thinner amphibolitic dikes are strongly deformed, boudinaged and brecciated, forming agmatites or typical schollenmigmatites with trondhjemitic mobilisate and angular mafic fragments (Fig. 7). This rock resembles the schollenmigmatites on the Haukivesi area, which have been mapped in the surroundings of the nickel-bearing mafic and ultramafic intrusions of that area (Gaál and Rauhamäki, 1972). The schollenmigmatites are results of both tectonic and intrusive activity.

The leucocratic gneisses contain in some parts more biotite and grade into mica gneisses. In other parts hornblende bearing bands appear and the rock turns into banded hornblende gneiss.

In the banded hornblende gneiss from a millimeter to several centimeters thick hornblende-rich bands alternate with leucocratic ones. The rock is migmatized by a mobilisate of trondhjemitic composition.

The major minerals of the rock are oligoclase, hornblende and quartz. The minor minerals are chlorite, potassium feldspar and biotite, the accessoric components being opaques, apatite, zircon and epitode. The hornblende gneiss has been met with as intercalation in the mica gneisses in the northern part of the area.

The structural development of similar gneisses has been studied in well exposed areas of West Greenland, where it could be demonstrated that progressive deformation of plutonic granitoid rocks with mafic inliers results in banded gneisses (Myers, 1978). Similar development has been envisaged in the Kotalahti area. The major part of the banded gneisses is formed by trondhjemite, which has been strongly foliated and intruded by mafic dikes. During progressive deformation the trondhjemite became deformed together with the amphibolite dikes and a light trondhjemitic mobilisate migmatized the 


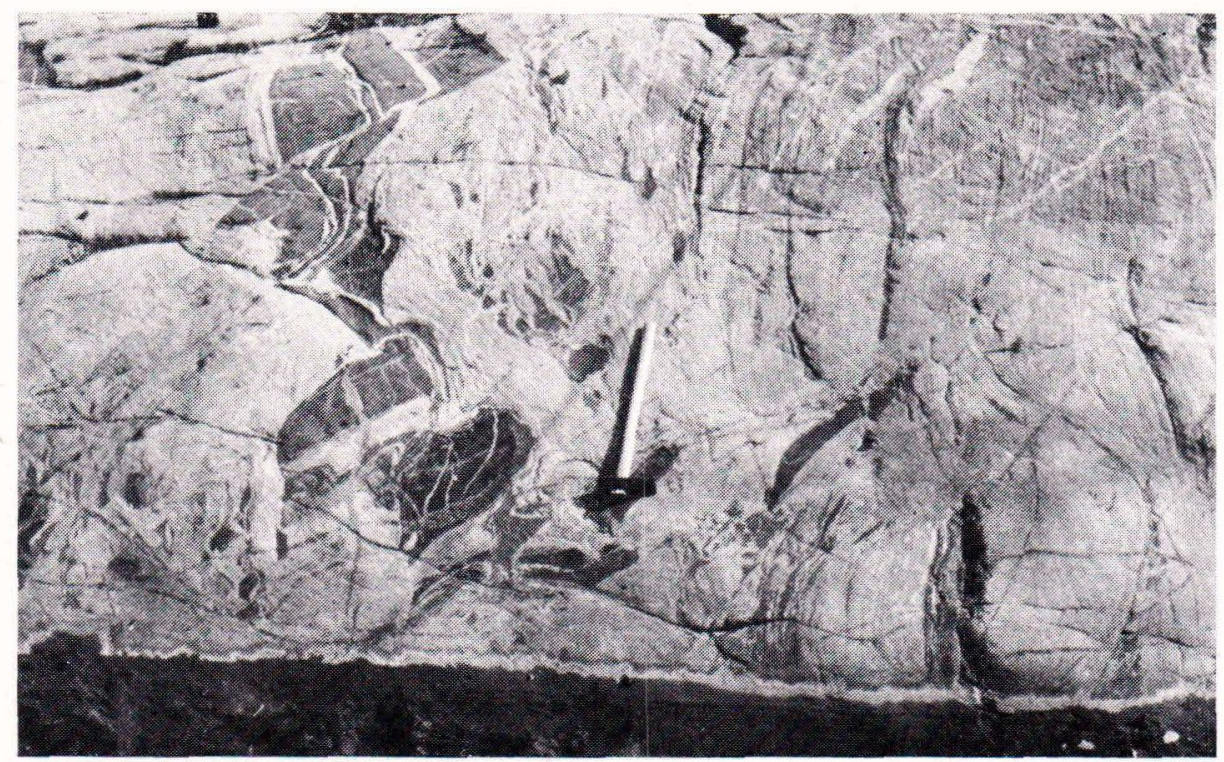

Fig. 7. Banded leucocratic gneiss with brecciated fragments of amphibolitic dikes. Vehka open pit, Kotalahti mine.

complex. At this stage the agmatites and schollenmigmatites were formed. Extreme deformation in the upper part of the complex produced out of these components the banded gneisses, which might represent a zone of shear below the mica gneiss group.

\section{Mica gneiss group}

The major minerals of the mica gneiss are oligoclase, quartz and biotite. In the narrow NW-SE trending mica gneiss belt south the Valkiajärvi brachyantiform porphyroblasts of garnet, sillimanite and pinitized cordierite are met with. Minor and accessoric minerals potassium feldspar, apatite, zircon and opaques. Round calc-silicate concretions or boudinaged layers are typical. The mica gneisses are invariably veined by a leucocratic trondhjemite mobilisate. The relative abundance of mobilisate increases from NW to $\mathrm{SW}$, in the northeastern corner of the area being about $10 \%$ and in the vicinity of the deposit 40 to $50 \%$. In the SW-part of the area the veined gneisses are intruded by a younger porphyritic granite. This granite has large oligoclase phenocrysts and, as other major components, potassium feldspar, quartz and muscovite. Potassium feldspar in places replaces plagioclase. Minor and accessoric components are chlorite, carbonate, epidote, sphene and opaques.

Mineral ages and their bearing on the stratigraphy

In order to study age relations, samples have been taken from the granite gneiss, the leucocratic gneiss and mafic plutonic rocks of the Kotalahti deposit. U-Pb age determinations on zircons and sphene were carried out by O. Kouvo of the Geochronological Laboratory of the Geological Survey of Finland. $\mathrm{K}$-Ar age determinations on biotite have been done by F. J. Fitch, FM Consultants, Herne Bay, Kent, England.

The analytical results are shown in Tables 2 and 3 and the concordia plot of the $\mathrm{U}-\mathrm{Pb}$ determinations in Fig. 8. Sample numbers are 
Table 2. Analytical results of the U-Pb age determ:nations on zircon and sphene of the Kotalahti area

\begin{tabular}{|c|c|c|c|c|c|}
\hline \multirow{2}{*}{$\begin{array}{l}\text { Sample } \\
\text { No. }\end{array}$} & \multirow{2}{*}{ Rock } & \multirow{2}{*}{$\begin{array}{c}\text { Zircon } \\
\text { fraction } \\
\mathrm{d}=\mathrm{g} . \mathrm{cm}^{-3} \\
\emptyset=\mu \mathrm{m}\end{array}$} & \multirow{2}{*}{$\begin{array}{l}238 \mathrm{U} \\
\mu \mathrm{g} / \mathrm{g}\end{array}$} & \multirow{2}{*}{$\begin{array}{c}{ }^{206} \mathrm{~Pb} \\
\operatorname{radiogenic} \\
\mu \mathrm{g} / \mathrm{g}\end{array}$} & \multirow{2}{*}{$\frac{{ }^{206} \mathrm{~Pb}}{{ }^{204} \mathrm{~Pb}}$} \\
\hline & & & & & \\
\hline A356B & Leucocratic gneiss & +4.6 & 64.2 & 24.0 & 1123 \\
\hline A356C & 》 & $4.2-4.6$ & 126.0 & 50.7 & 725 \\
\hline A362A & Granite gneiss & total & 552.2 & 190.1 & 853 \\
\hline A362B & y & +4.6 & 376.3 & 139.5 & 1735 \\
\hline $\mathrm{A} 362 \mathrm{C}$ & $»$ & $4.2-4.6$ & 479.5 & 170.9 & 804 \\
\hline A362D & $»$ & $4.0-4.2$ & 659.9 & 216.8 & 524 \\
\hline $\mathrm{A} 362 \mathrm{E}$ & $»$ & titanite & - & - & - \\
\hline A357A & $»$ & total & 520.1 & 168.2 & 1001 \\
\hline A $357 \mathrm{~B}$ & $»$ & titanite & 80.5 & 22.4 & 75 \\
\hline $\mathrm{A} 446 \mathrm{~A}$ & diorite & total & 407.3 & 115.1 & 2917 \\
\hline $\mathrm{A} 446 \mathrm{~B}$ & $》$ & +4.2 & 351.9 & 100.6 & 8094 \\
\hline A $446 \mathrm{C}$ & $»$ & $4.0-4.2$ & 659.5 & 181.3 & 8371 \\
\hline A701A & gabbro & $+4.2 /+130$ & 398.3 & 113.7 & 11731 \\
\hline A701B & $\gg$ & $+4.2 /-130$ & 454.7 & 130.1 & 11579 \\
\hline A701C & $»$ & $4.0-4.2 /+70$ & 150.3 & 410.9 & 9563 \\
\hline
\end{tabular}

Least squares calculated according to York (1966).

For half lifes of $235 \mathrm{U}$ and $238 \mathrm{U}$ the values given

by Jaffey et al. (1971) have been used.

Sample A356 is a leucocratic gneiss of trondhjemitic composition from the wall rock of the Vehka ore body, Vehka open pit, with location $\mathrm{x}=6940,93$ and $\mathrm{y}=531.675$.

Sample A362 is a migmatitic granite gneiss from the Valkeinen brachyantiform with location $\mathrm{x}=$ 6940.67 and $\mathrm{y}=532.69$.
Sample A357 is a banded, medium-grained granite gneiss of pink colour from the Paukarlahti dome, situated NW from the Kotalahti area with location $\mathrm{x}=6945,82$ and $\mathrm{y}=530,11$. The Paukarlahti dome is the second southernmost gneiss dome of the Kuopio district, which has been classified as basement since the pioneer mapping of W. W. Wilkman (1938). serial numbers of the Geochronological Laboratory of the Geological Survey of Finland.

The zircons of the granite gneiss of Valkeinen yield strongly discordant ages. The sample A362 is represented by four fractions. The $\mathrm{Pb}^{206 / \mathrm{U}^{238}}$ and $\mathrm{Pb}^{207} / \mathrm{U}^{235}$ mole rations define a linear array which has an upper intercept on the concordia curve at $2857 \pm 49$ $\mathrm{Ma}$ and a lower intercept at $1746 \pm 51 \mathrm{Ma}$. If samples A357-Paukarlahti and A356-Vehka are combined, data define an excellent discordia array having an upper intercept of $2795 \pm 13 \mathrm{Ma}$ and a lower intercept of $1670 \pm 13$ Ma. Following the treatment of

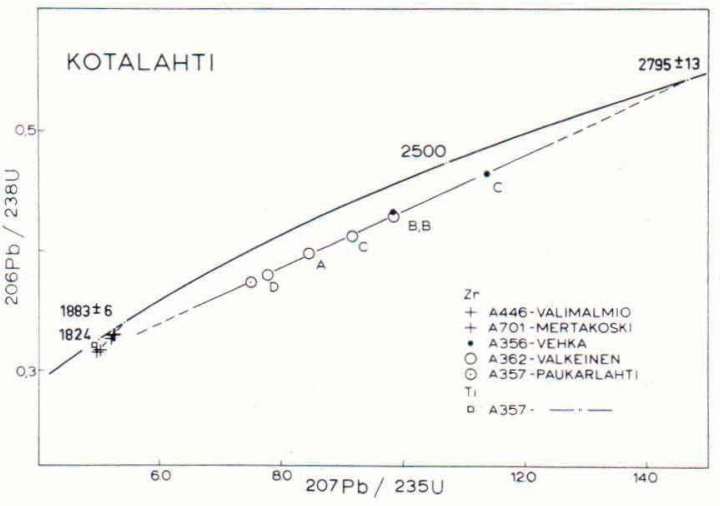

Fig. 8. Concordia diagram of $\mathrm{U}-\mathrm{Pb}$ determination on zircons and sphene in the Kotalahti area, by O. Kouvo, Geological Survey of Finland. 
by O. Kouvo, Geological Survey of Finland.

\begin{tabular}{|c|c|c|c|c|c|}
\hline \multirow{2}{*}{\multicolumn{3}{|c|}{$\begin{array}{l}\text { Isotopic abundance } \\
\qquad{ }^{206} \mathrm{~Pb}=100\end{array}$}} & \multicolumn{3}{|c|}{ Age (million years) } \\
\hline & & & \multirow{2}{*}{$\frac{{ }^{206} \mathrm{~Pb}}{{ }^{238} \mathrm{U}}$} & \multirow{2}{*}{$\frac{207 \mathrm{~Pb}}{235 \mathrm{U}}$} & \multirow{2}{*}{$\begin{array}{l}{ }^{207} \mathrm{~Pb} \\
{ }^{206} \mathrm{~Pb}\end{array}$} \\
\hline 204 & 207 & 208 & & & \\
\hline .07842 & 17.539 & 12.244 & $2318 \pm 14$ & $2418 \pm 8$ & $2504 \pm 7$ \\
\hline .13186 & 19.461 & 12.187 & $2461 \pm 14$ & $2554 \pm 9$ & $2628 \pm 7$ \\
\hline .10944 & 16.867 & 14.446 & $2159 \pm 21$ & $2280 \pm 14$ & $2390 \pm 15$ \\
\hline .05443 & 17.421 & 20.884 & $2298 \pm 15$ & $2419 \pm 9$ & $2523 \pm 6$ \\
\hline .12060 & 17.714 & 10.922 & $2223 \pm 15$ & $2352 \pm 9$ & $2467 \pm 6$ \\
\hline .18741 & 17.311 & 12.819 & $2074 \pm 14$ & $2204 \pm 9$ & $2327 \pm 8$ \\
\hline$\overline{08744}$ & & - & & & $\begin{array}{l}1850 \\
2293+12\end{array}$ \\
\hline .08744 & 15.746 & 11.969 & $2047 \pm 13$ & $2172 \pm 9$ & $2293 \pm 12$ \\
\hline 1.3064 & 29.226 & 76.118 & $1795 \pm 12$ & $1808 \pm 12$ & $1824 \pm 22$ \\
\hline .02299 & 11.876 & 15.501 & $1822 \pm 11$ & $1849 \pm 7$ & $1880 \pm 10$ \\
\hline .00940 & 11.713 & 14.687 & $1840 \pm 11$ & $1861 \pm 7$ & $1884 \pm 5$ \\
\hline .01025 & 11.696 & 14.860 & $1778 \pm 11$ & $1825 \pm 6$ & $1880 \pm 5$ \\
\hline .006034 & 11.634 & 13.746 & $1838 \pm 11$ & $1857 \pm 6$ & $1879 \pm 5$ \\
\hline .006161 & 11.624 & 14.999 & $1841 \pm 11$ & $1858 \pm 7$ & $1877 \pm 4$ \\
\hline .008215 & 11.591 & 8.467 & $1769 \pm 16$ & $1814 \pm 9$ & $1867 \pm 4$ \\
\hline
\end{tabular}

Sample A446 is a diorite from the lower unmineralized part of the Mertakoski-Vehka intrusive body, below the Välimalmio ore body.

Sample A701 is a gabbro associated with the Mertakoski ore body.

Wetherill (1956) it is clear from Fig. 8 that these data are compatible with episodic loss of lead about $1700-1800 \mathrm{Ma}$ ago. The ages of $1824 \mathrm{Ma}$ for titanite A357 and $1850 \mathrm{Ma}$ for titanite A362 indicate some element redistribution. Based on analogy with the Kuo- pio gneiss domes and the basement complex of eastern Finland (Wetherill et al., 1962; Kouvo and Tilton, 1966), it is concluded that the zircons indicate about $2800 \mathrm{Ma}$ age of the granite gneisses of Valkeinen and Paukarlahti. The biotite ages of the granite gneiss samples around $1730 \mathrm{Ma}$ and $1670 \mathrm{Ma}$ are in agreement with the $\mathrm{K}-\mathrm{Ar}$ ages of biotite of the Kuopio gneiss domes in samples A53 and $\mathrm{A} 43$ as $1730 \mathrm{Ma}$ and $1760 \mathrm{Ma}$ (Kouvo and Tilton, 1966). According to the lower intercept

Table 3. Analytical results of the K-Ar age determinations on biotite of the Kotalahti area by F. J. Fitch.

\begin{tabular}{|c|c|c|c|c|c|c|c|}
\hline $\begin{array}{l}\text { Sample } \\
\text { No. }\end{array}$ & Rock & Method & $\mathrm{K}_{2} \mathrm{O}$ & $\begin{array}{l}\text { Atmospheric } \\
\text { contami- } \\
\text { nation }\end{array}$ & $\mathrm{v} / \mathrm{m}$ & $\begin{array}{l}\text { Apparent } \\
\text { age and } \\
\text { errors m.y. }\end{array}$ & $\begin{array}{c}\text { Average apparent } \\
\text { age and errors } \\
\text { m.y. }\end{array}$ \\
\hline \multirow[t]{3}{*}{ A 356} & leucocratic & biotite & 7.65 & 2.8 & 0.7132 & $1724 \pm 34$ & \multirow{3}{*}{$1724 \pm 34$} \\
\hline & gneiss & & 7.65 & 2.8 & 0.7121 & $1721 \pm 34$ & \\
\hline & & & 7.65 & 2.3 & 0.7140 & $1726 \pm 34$ & \\
\hline \multirow[t]{3}{*}{ A 362} & granite & biotite & 8.89 & 2.2 & 0.833 & $1731 \pm 35$ & \multirow{3}{*}{$1731 \pm 35$} \\
\hline & gneiss & & 8.89 & 2.1 & 0.834 & $1731 \pm 35$ & \\
\hline & & & 8.89 & 2.1 & 0.833 & $1730 \pm 35$ & \\
\hline \multirow[t]{3}{*}{ A 357} & granite & biotite & 7.53 & 3.0 & 0.666 & $1663 \pm 50$ & \multirow{3}{*}{$1675 \pm 50$} \\
\hline & gneiss & & 7.53 & 2.7 & 0.680 & $1687 \pm 51$ & \\
\hline & & & 7.53 & 2.6 & 0.672 & $1674 \pm 50$ & \\
\hline
\end{tabular}

Constant used: $\lambda_{\mathrm{e}}=0.584 \times 10^{-10} \mathrm{yr}^{-1}$

$\lambda_{\beta}=4.72 \times 10^{-10} \mathrm{yr}^{-1}$

$\mathrm{v} / \mathrm{m}=$ volume of radiogenic argon in $\mathrm{mm}^{3}$ N.T.P. per gr of sample 
on the concordia diagram it is possible to interpret the biotite age as result of a major metamorphic overprinting event.

The zircon of the leucocratic gneiss of Vehka differs considerably from the zircons of the gneiss granite, being poor in uranium, more transparent and heterogenous in habitus. The crystals are euhedral with tetragonal prisms and platy shapes. Furthermore sample A356 contains anomalously much zircon producing 6.5 grams of zircon out of $40 \mathrm{~kg}$ of rock. The zircon does not point to a detrital material. The leucocratic gneisses resemble granite gneisses in rock type, metamorphic grade and deformation and both of them contain amphibolitic dikes. Thus a completely different interpretation for the leucocratic gneisses than for those of the granite gneisses would be artificial and the primary age similar to those of the granite gneisses must be accepted for them.

Zircons of the Vehka-Mertakoski intrusive body give a slightly discordant age of $1883 \pm 6$ $\mathrm{Ma}$. Since the intrusion has taken place in connection with folding it is possible to date this deformation at around $1890 \mathrm{Ma}$.

It was concluded that the granitoidic parent rocks of the granite gneisses and leucocratic gneisses crystallized around 2800 $\mathrm{Ma}$ ago. Since these gneisses contain inliers and inclusions of the epicontinental group, it must be assumed that the rocks of the epicontinental group are older than $2800 \mathrm{Ma}$. This rather surprising result should be discussed in the regional context.

The Valkeinen brachyantiform, discovered during the field work of this study, was found to be the southernmost representative of the Kuopio gneiss domes. Wilkman (1938) classified the granite gneisses of the Kuopio gneiss domes as the basement to older schists, comprising quartzites, graphite schists, carbonate and calc-silicate rocks overlaid by mica gneisses. These schists, also known as
Savo schists, were regarded older than the overlaying Kalevian of the Karelian orogeny.

Later the Savo schists have been correlated with the rocks of the Karelian belt (Preston, 1954). After mineral age determinations from the gneiss granites yielded Archean ages (Wetherhill et al., 1962: Kouvo and Tilton, 1966) the Savo schists were regarded as Proterozoic and they are now generally accepted to belong to the supergroup of the Svecokarelian schists (Simonen, 1971). Some problems, however, remained and it has been recognized, that both in Kuopio and south of Kuopio, the Archean-Proterozoic boundary is obscure. This has been attributed to the high grade of metamorphism and remobilization of the basement during the Svecokarelian event. Preston (1954, p. 12) states: »Where all rocks have been subject to agencies of granitization and migmatites are dominant, quartzite and calc-silicate rocks are likely to be the only relicts of this sequence, and gneiss on one side will be indistinguishable from gneiss on the other». In the present study gneisses on both sides of the epicontinental group have been found to be older than $2800 \mathrm{Ma}$ and inclusions of the epicontinental group are met with in the granite gneiss complex. Leucocratic microline granite migmatizes both granite gneiss and the quartzites, being distinctly the youngest rock type of undetermined age.

Only the mica gneiss group is left as of probably Proterozoic age.

\section{Structural history}

Polyphase folding, deep-seated ductile faults and high metamorphic grade with migmatization render the structural analysis of the Kotalahti area especially difficult. This has been taken into account during the field work and special attention has been paid to the registration of several generations of foliation, lineations, migmatite structures and 
dike and vein orientations. Also the geophysical maps have been extensively used to aid the structural analysis. The rocks of the epicontinental group show up well in the magnetic and electric maps. For example the slingram anomalies indicate the distribution of graphite schists, rocks which are usually poorly exposed, and the Bouguer anomaly map gives information about the extent of the mafic-ultramafic plutonic rocks.

The structural interpretation of the field data is displayed in the foliation and lineation maps. The foliation maps show strike and dip of the foliations $s_{1}$ to $s_{5}$ belonging to folding phases $F_{1}$ to $F_{5}$ (Fig. 9). Since the great number of determinations cannot be displayed on the map, average values have been computed for values with less than $30^{\circ}$ scatter. On the lineation map the plunge of fold axes, minor fold axes and lineations is shown for $l_{3}, l_{4}$ and $1_{5}$, generated during the folding phases $\mathrm{F}_{3}, \mathrm{~F}_{4}$ and $\mathrm{F}_{5}$ (Fig. 10). Repeated deformation makes the interpretation of lineation problematic and the relative-age classification on Fig. 10 must be regarded as somewhat hypothetical. According to the general usage $l_{3}$ is parallel to the intersection line of $s_{3}$ with $s_{1}$ and/or $s_{2}$. Similarly $l_{4}$ is the intersection of $\mathrm{s}_{4}$ with $\mathrm{s}_{1}$ and/or $\mathrm{s}_{2}$ and/or $\mathrm{s}_{3}$.

The first recognizable deformation, $F_{1}$, is reflected in the complicated internal fold patterns of the epicontinental group as seen for example in the wall rocks of the Jussi ore body. Since primary sedimentary structures have not been observed in the area, $F_{1}$ is very little known. It is assumed, that the granite gneisses, the leucocratic gneisses and the banded hornblende gneisses have been foliated during $F_{1}$ and that the amphibolitic dikes intruded conformably with $s_{1}$ in Archean times.

The second phase of deformation, $\mathrm{F}_{2}$, produced in the central part of the area a large antiform with the granite gneiss core and inclined or recumbent axial plane (Fig. 9). Other $\mathrm{F}_{2}$ folds could not be indentified in the area and it is difficult to conclude the primary trend of the $F_{2}$ folds. The amphibolite dikes have been foliated during $\mathrm{F}_{2}$ and the banding of the gneisses has been produced by strong deformation during this phase. There are no unambiguous criteria to date $F_{2}$. If the mica gneiss group is of Proterozoic age $\mathrm{F}_{2}$ is Proterozoic, since if deforms the mica gneisses.

During the third deformation phase, $F_{3}$, the strain was comparatively low and $s_{3}$ axial plane schistosity is weakly developed. The banded gneisses with $\mathrm{s}_{1} / \mathrm{s}_{2}$ composite foliation became refolded into flexural flow type of folds. The $\mathrm{F}_{2}$ antiform has been refolded in $\mathrm{N}-\mathrm{NNW}$ trending synforms and antiforms with subvertical axial planes (Fig. 4). The Kotalahti synform has been formed at this stage and the Valkeinen brachyantiform, essentially an $\mathrm{F}_{2} / \mathrm{F}_{3}$ interference structure, with the Valkeajärvi gabbro complex in its core. Another $\mathrm{F}_{3}$ antiform was formed in the western part of the area with granite gneiss in its core. The mafic to ultramafic plutonic rocks intruded during $\mathrm{F}_{3}$ and it is concluded from the zircon age of the Kotalahti plutonic complex, that $\mathrm{F}_{3}$ took place around $1900 \mathrm{Ma}$ ago.

In the fourth deformation phase, $\mathbf{F}_{4}$, a zone of high strain and intensive refoliation developed with NW-SE strike and subvertical dip. The $s_{4}$ foliation intersects the $F_{3}$ antiform in the SE part of the area, which makes $\mathrm{F}_{4}$ distinctly younger than $\mathrm{F}_{3}$. However, it is likely that $\mathrm{F}_{4}$ followed $\mathrm{F}_{3}$ in an uninterrupted deformation process in which the E-W compression was released in a left hand transcurrent movement. Thus the $\mathrm{F}_{3}$ synforms and antiforms were bent in S-shapes in a ductile shear zone in which also the $s_{4}$ foliation formed, first at an angle to the shear zone, but later, as the transcurrent movement went on, rotated into a position parallel to the 


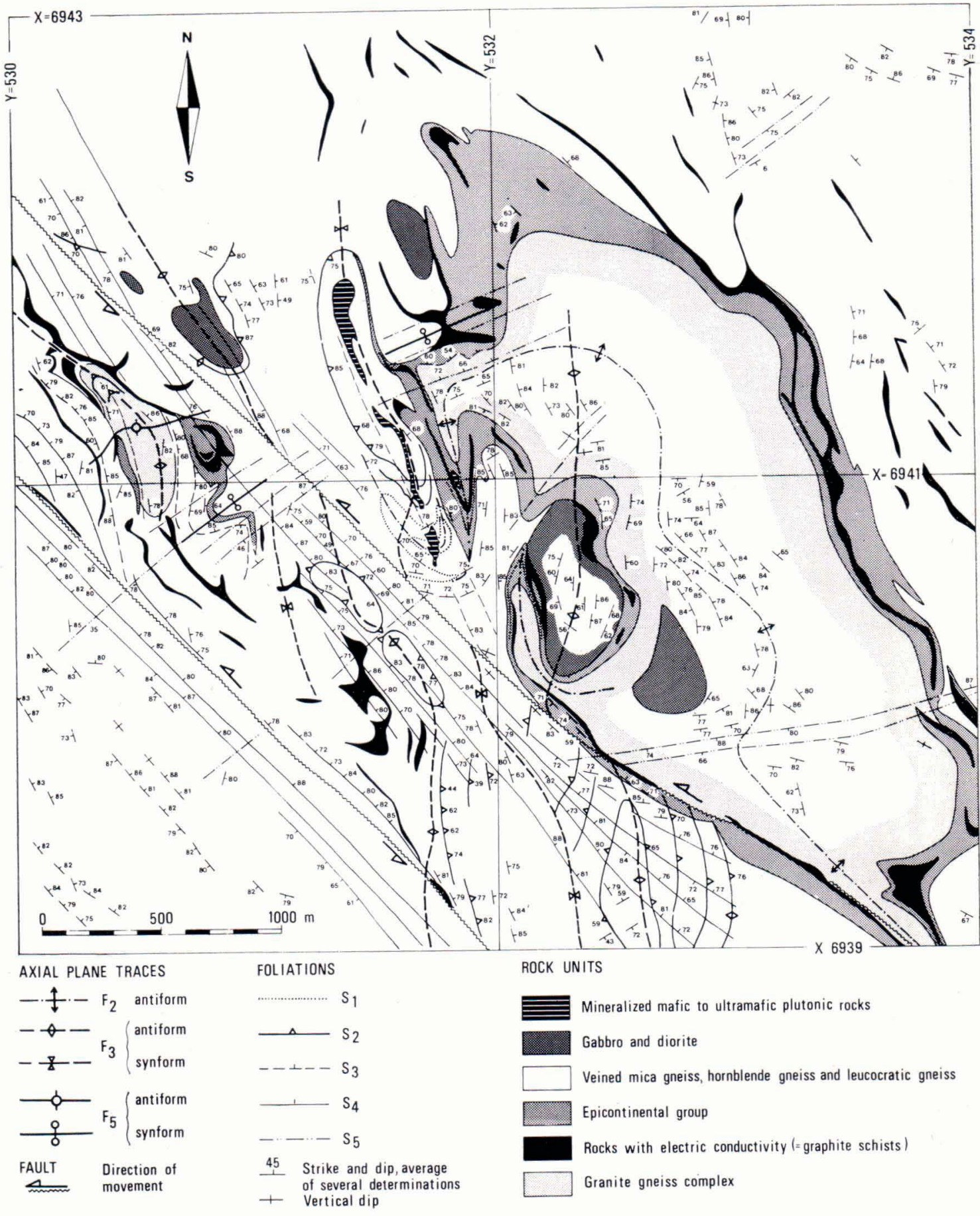

Fig. 9. Foliations of the Kotalahti area. 


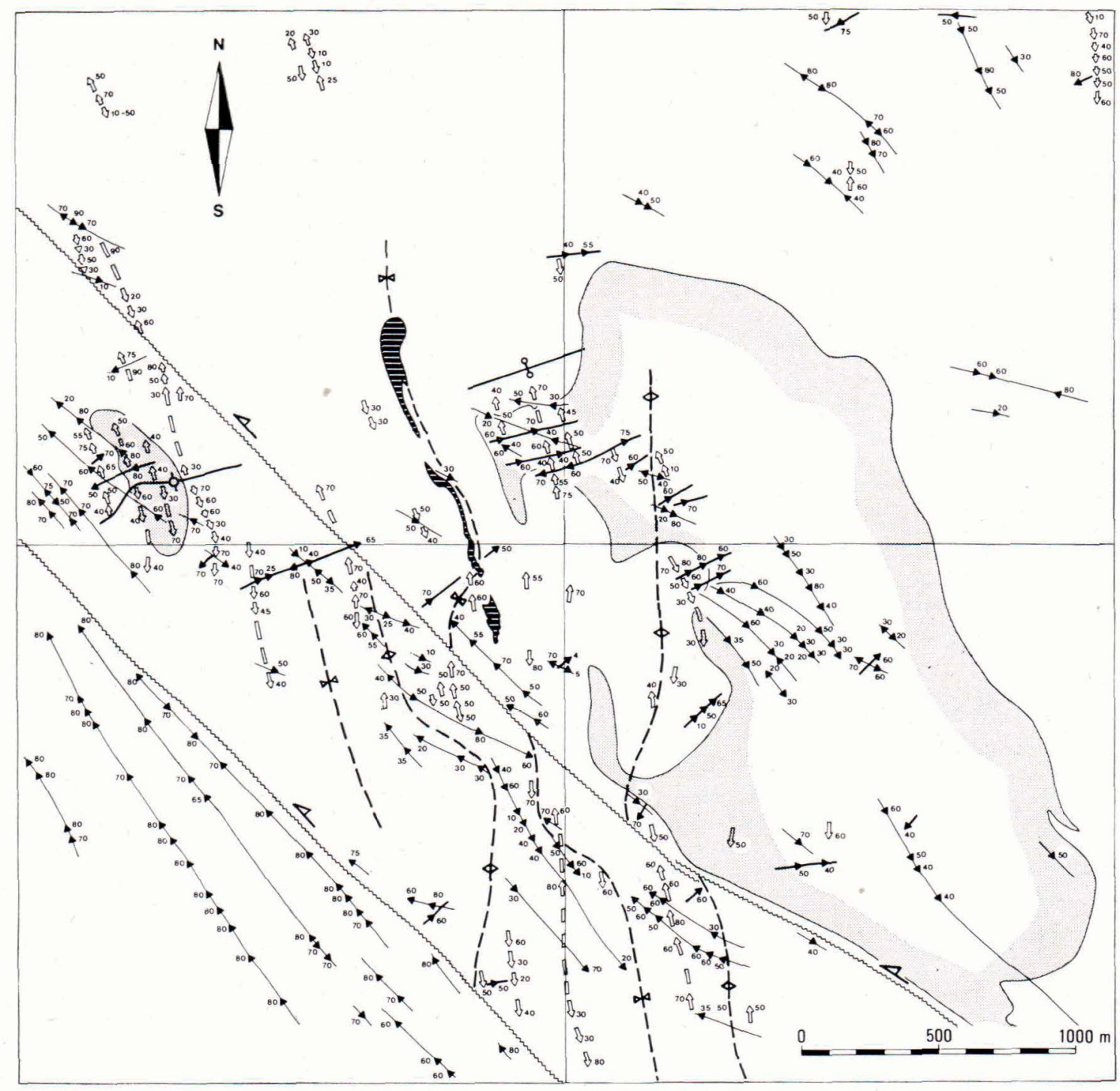

AXIAL PLANE TRACES

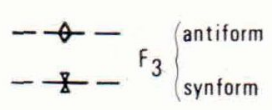

$\mathrm{F}_{5}$ antiform $_{\text {synform }}^{\phi}$

FAULT $\begin{aligned} & \text { Direction of } \\ & \text { movement }\end{aligned}$
ROCK UNITS

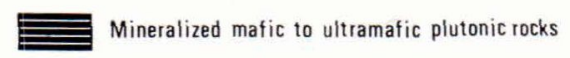

$\square$ Granite gneiss complex

Fig. 10. Lineations and fold axes of the Kotalahti area. 
shear zone. The shear zone had probably also a vertical component of movement, which caused further parallelism of $s_{4}$ with the shear zone. The mechanism and theoretical aspects of ductile shear belts have been dealt with by Ramsay and Graham (1970). The Kotalahti fault line marks the central line of the shear belt. It is a young fracture, which is assumed to be a comparatively late revival of the ductile shear belt.

The fifth deformation phase, $\mathrm{F}_{5}$ appears in narrow ENE trending belts which can be in a few cases identified as culminations and depressions upon the $F_{3}$ folds, for instance in the Koirusjärvi brachyantiform and the Kotalahti brachysynform (Fig. 3).

\section{Mafic and ultramafic plutonic rocks}

The bulk of the mafic to ultramafic plutonic rocks of the area occur in a NW-SE trending narrow belt north of the Kotalahti fault line. Three plutonic complexes can be distinguished. They are from NW to SE: the Ritolahti gabbro, the Kotalahti mafic-ultramafic plutonic complex and the Valkiajärvi gabbro complex (Fig. 3). The belt of the mafic and ultramafic plutonic rocks extends further to SE into the Haukivesi area (Gaál and Rauhamäki, 1972) and to NW.

\section{The Kotalahti mafic to ultramafic plutonic complex}

The Kotalahti mafic to ultramafic plutonic complex comprises three small mineralized intrusive bodies, situated in the oval-shaped Kotalahti brachysynform with wall rocks of leucocratic gneisses (Fig. 11).

The largest body is the Mertakoski-Vehka intrusive body, which is a roughly triangular plate parallel to the axial plane of the synform, on average 50 to 100 meters thick, dipping $75^{\circ}$ towards ENE (Fig. 12). The out- cropping length of the body is $1000 \mathrm{~m}$ and its maximum depth $700 \mathrm{~m}$. At its bottom the plate bulges up to $200 \mathrm{~m}$ thickness. The plutonic rocks of the Mertakoski-Vehka intrusive body form a differentiation series from peridotites to quartz diorite.

The following description of the rocks is given according to Papunen (1970) and Papunen and Koskinen (1970). The peridotites are predominantly harzburgites and lherzolites and subordinately dunite. The characteristic rock type of the intrusion is an altered pyroxenite, perknite, in which about half of the pyroxenes is altered into colourless tremolite or cummingtonite and hornblende. Gabbros are olivine gabbro, olivine norite, norite, pyroxene gabbro and hornblende gabbro. The more mafic gabbros are often distinguished by larger poikilitic crystals of plagioclase. The hornblende gabbros show ophitic texture.

All the above rocks are cut by fine-grained granoblastic gabbroic to quartz dioritic as well as trondhjemitic and granitic dikes.

The vertical zoning of the differentiation products within the intrusive body is reversed. The ultramafic rocks are in the upper part of the intrusion and gabbros in the lower part. The least mafic differentiates, diorite and quartz diorite are in the lowermost part. Accordingly, mineralization occurs in the upper part of the body, predominantly in ultramafic rocks, but also in the more mafic gabbros.

Papunen et al. (1979) interpret the ophitic hornblende gabbro and the diorite to quartz diorite as a result of the contamination of the ultramafic magma with the trondhjemitic

Fig. 11. Structural map of the Kotalahti nickelcopper deposit. Pi-diagram nr 1: 57 foliations (contoured with isolines $1-3.5-6-8.5-11-13.5 \%$ ), 4 fold axes (circles) and 11 lineations (crosses) $\mathrm{Pi}$ diagram $\mathrm{nr}$ 2a: 414 foliations (contoured with isolines $1-2-3-4-5-6 \%$ ), 17 fold axes (circles) and 40 lineations (crosses) Beta-diagram $\mathrm{nr} 2 \mathrm{~b}$ : 414 foliations, contours $1-3-5-7-9-11-13 \%$. 


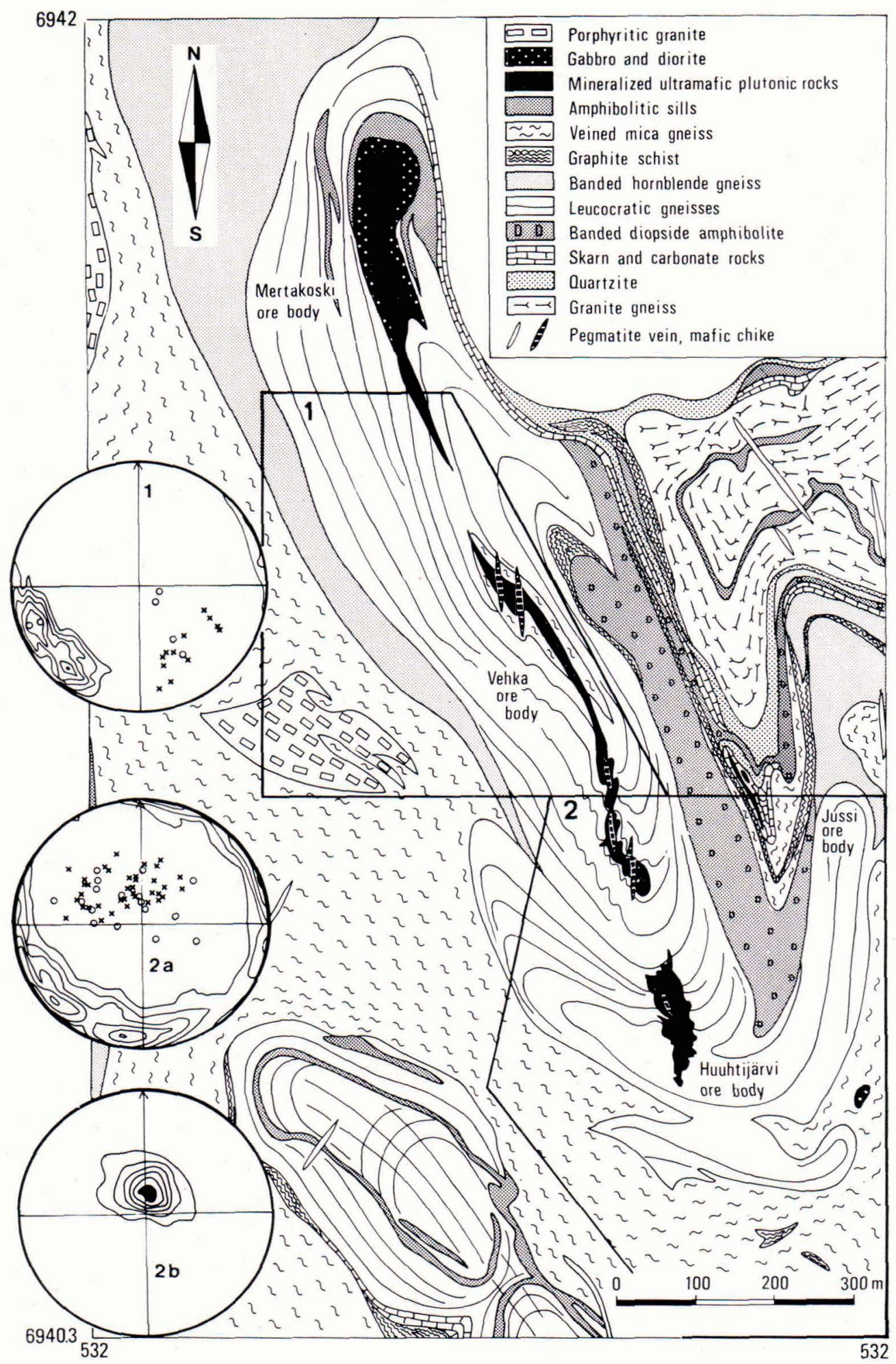


Table 4. Sequence of the intrusion and structural events as determined in the Vehka open pit (see Fig. 13).

(1) Leucocratic gneiss with strong foliation $\left(\mathrm{s}_{1}\right)$

(2) Amphibolitic dikes I, foliation (s2)

(3) Amphibolitic dikes II, cutting amphibolite dikes I, folded, boudinaged in connection with the $F_{3}$ event

(4) $\mathrm{F}_{3}$ left hand folds

(5) Perknite + gabbro intrusion + disseminated sulphide ore

(6) Tonalitic veins brecciating the perknite

(7) Amphibolite III dikes intruding parallel to the axial plane of the $F_{3}$ folds, non-foliated

(8) Crosscutting pegmatite veins

(9) Remobilized sulphide ore intruding the contacts of amphibolite III and pegmatite veins and impregnating pegmatite

neosome of the surrounding leucocratic gneisses.

The Huuhtijärvi intrusive body has the shape of a slightly compressed pipe which plunges $80^{\circ}$ towards NNW down to a depth of over $750 \mathrm{~m}$. The pipe is parallel to the fold axis of the Kotalahti brachysynform, as demonstrated by the pi- and beta-diagrams on Fig. 11. The Huuhtijärvi intrusive body consists almost entirely of mineralized perknite.

The sword shaped Jussi intrusive body plunges $75^{\circ}$ towards north and extends below the depth of $750 \mathrm{~m}$. It is emplaced in the hinge zone of a subvertical fold within rocks of the epicontinental group, intruded by numerous pegmatite dikes. Sulfides, as massive ore in crosscutting veins and breccia type of ore, are quantitatively predominating over the host-rock perknite, which is met with as a brecciated pipe between the +200 and +400 levels (Papunen and Koskinen, 1978).

The relation of the intrusion to the wall rocks has been studied in detail by the author in the Vehka open pit (Fig. 13). The outcrop surface has been mapped in the scale $1: 100$ and the map redrawn in scale $1: 400$. The analysis of the map yielded important results

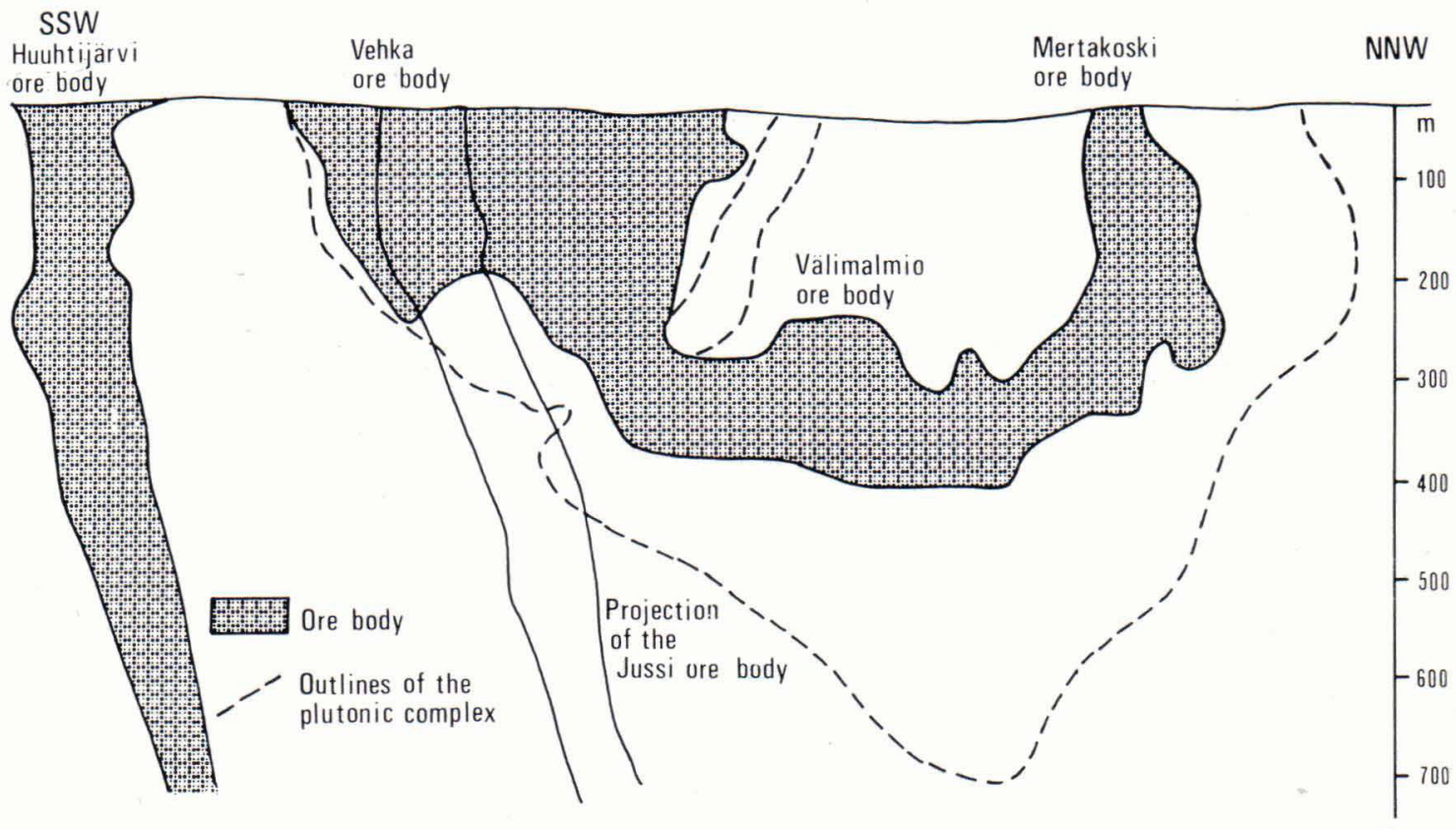

Fig. 12. Longitudinal projection of the Kotalahti mafic and ultramafic plutonic complex, after the geological staff of the Kotalahti mine. 


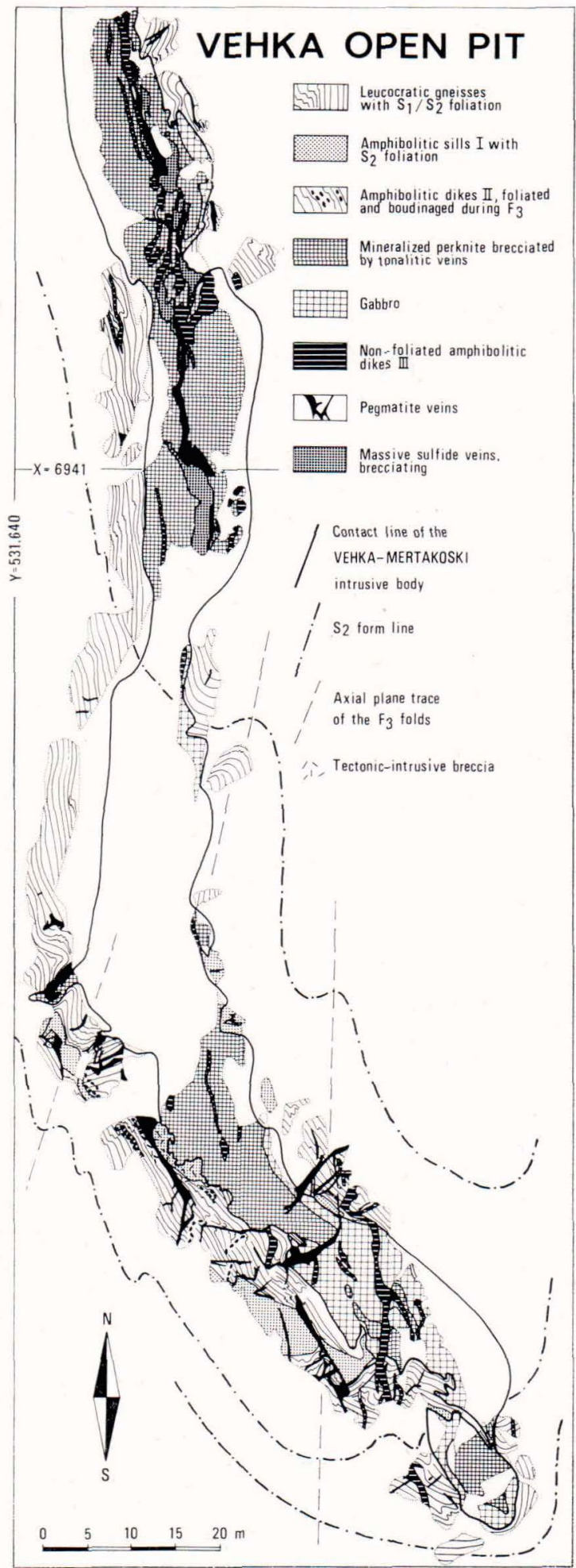

regarding the mechanism of the intrusion. The dominating structural feature is lefthand folding of the wall rock gneisses with steep NE-plunging axes. These folds have been correlated with the $\mathrm{F}_{3}$ deformation phase. The intrusive body forms a $10-15 \mathrm{~m}$ thick plate which is partly conformable with the foliation of the wall rock, partly crosscutting parallel to the $F_{3}$ axial plane. Based on contact relations a sequence of intrusion and structural events has been established (Table 2).

\section{The Valkiajärvi gabbro complex}

The Valkiajärvi gabbro complex consists of two large intrusive bodies and several small satellites, which are all parts of an oval-shaped massif of $500 \times 1000$ meters in size as judged from the gravimetric map and interpretation of gravimetric data (Figs. 14 and 15). The intrusion center of the gabbro complex is in the core of the Valkiajärvi brachyantiform (Fig. 9). The gabbro is wrapped into rocks of the epicontinental group, in which the foliation dips steeply away from the gabbro.

The main body has evolved in two distinct intrusion phases (Fig. 16). The first phase is made up predominantly by uralite gabbro with subordinate parts of pyroxene gabbro and occasional peridotitic parts. The rocks of the first phase are medium- to coarsegrained with an indistinct but macroscopically perceptible foliation. They contain inclusions of leucocratic gneiss, graphite gneiss, mica gneiss and amphibolite. The foliation and the inclusion trains define an antiform in the main body which has been identified in the

Fig. 13. Geological map and structural interpretation of the Vehka open pit. Geological mapping by the author and tachymetric survey by M. Aaltonen, Outokumpu Oy. For further explanation, see Table 2. 


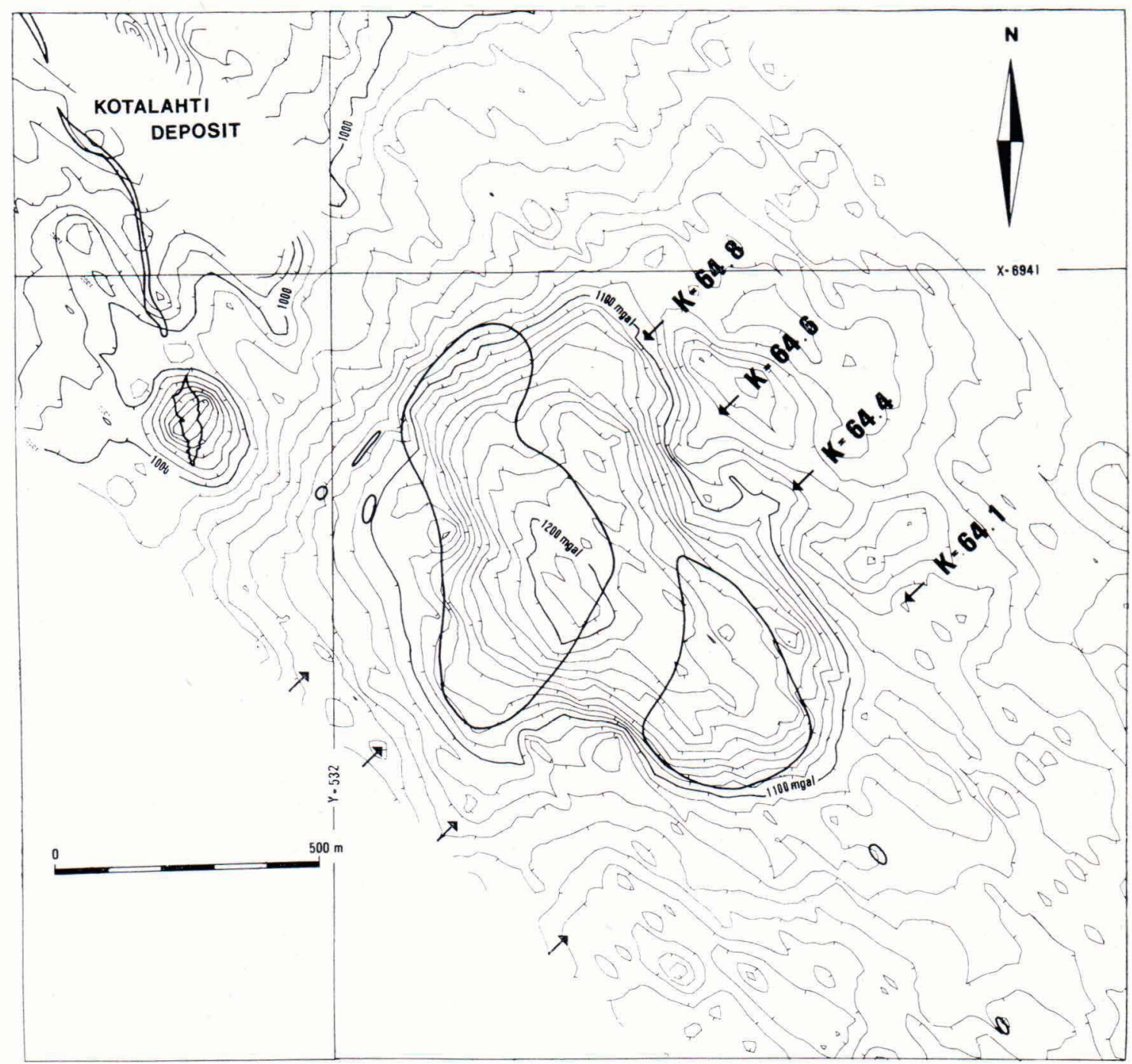

Fig. 14. Bouguer anomaly map of the surroundings of the Valkiajärvi gabbro complex with the outlines of the outcropping mafic and ultramafic plutonic bodies.

structural analysis as an $\mathrm{F}_{3}$ structure. The second intrusion phase occurs in NNWstriking dikes cutting the rocks of the first phase with sharp contacts parallel to the axial plane of the $\mathrm{F}_{3}$ antiform. It consists of a fine- to medium-grained non-foliated diabaselike hornblende gabbro. Chemical composition of the rocks of the first and second intrusion phases are given in Table 5 . The youngest rock is pegmatite which crosscuts gabbro in numerous diversely oriented dikes.

In the pyroxene gabbro the major minerals are pyroxene, in the first place enstatite but also augite, which are usually uralitized. The next major mineral, bytownitic or labra-

Fig. 15. Geophysical interpretation of the gravimetric data of the surroundings of the Valkiajärvi gabbro complex. 

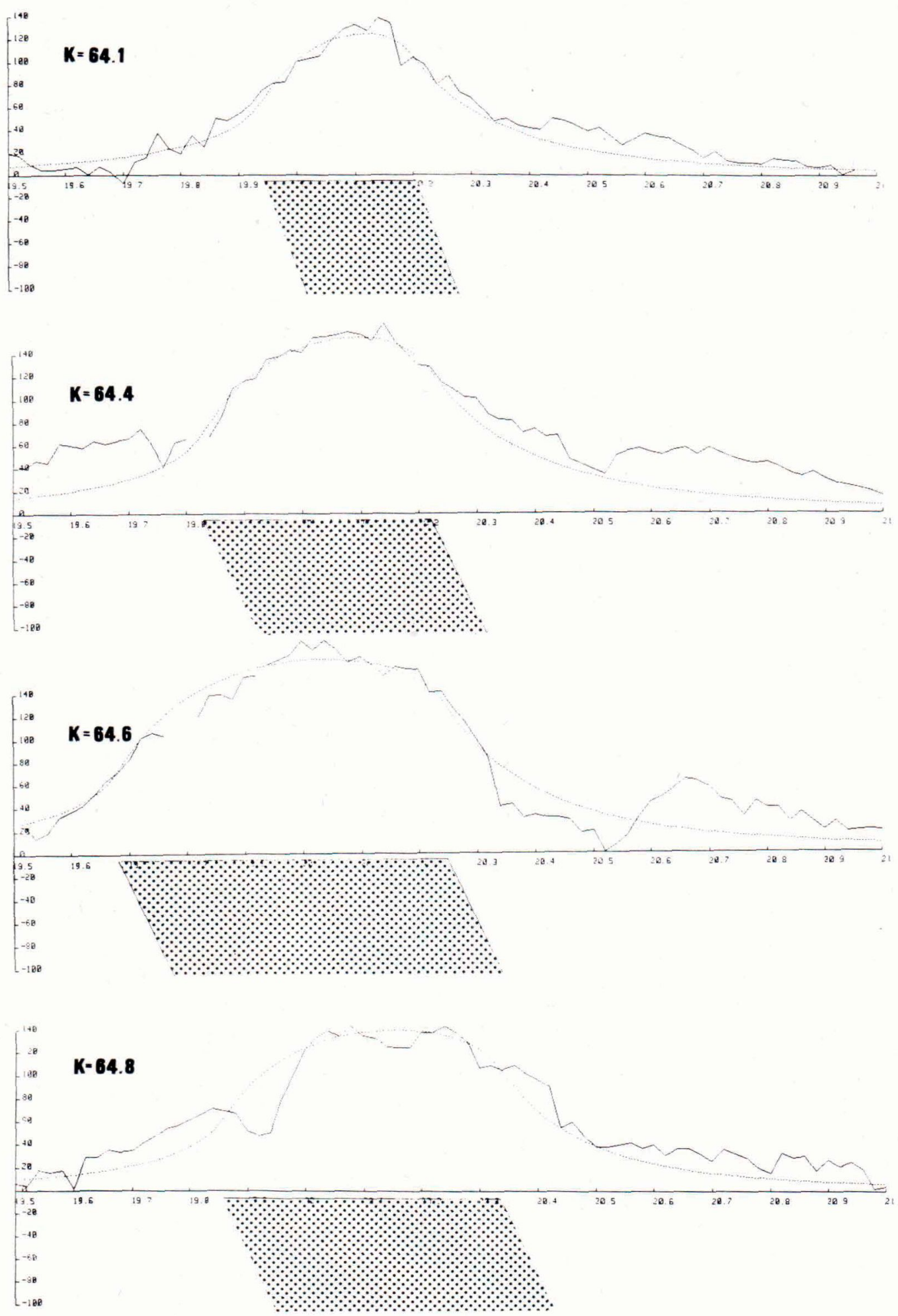
Table 5. Chemical composition of the Valkiajärvi gabbro complex. 1. Uralite gabbros and pyroxene gabbros of the first intrusion phase (27 analyses), 2. Hornblende gabbros of the second intrusion phase (8 analyses). For sample sites see Fig. 16A. $\mathrm{X}$-ray fluorescence analyses by the Geological Laboratory of the Outokumpu Oy.

\begin{tabular}{|c|c|}
\hline \multirow{2}{*}{$0 \%$} & $\begin{array}{l}\text { Arithmetic means and the errors } \\
\text { of arithmetic means }\end{array}$ \\
\hline & 1 \\
\hline
\end{tabular}

\begin{tabular}{|c|c|c|c|c|}
\hline $\mathrm{SiO}_{2} \%$ & \multicolumn{2}{|c|}{$51.2 \pm 0.2$} & \multicolumn{2}{|c|}{$51.6 \pm 0.7$} \\
\hline $\mathrm{TiO}_{2}$ & 0.80 & \pm 0.10 & 0.9 & \pm 0.2 \\
\hline $\mathrm{Al}_{2} \mathrm{O}_{3}$ & 10.8 & \pm 0.4 & 14.5 & \pm 0.6 \\
\hline $\mathrm{FeO}_{\text {tot }}$ & 9.7 & \pm 0.3 & 9.1 & \pm 0.7 \\
\hline $\mathrm{MnO}$ & 0.15 & \pm 0.01 & 0.14 & \pm 0.1 \\
\hline $\mathrm{MgO}$ & 12.4 & \pm 0.7 & 7.1 & \pm 0.8 \\
\hline $\mathrm{CaO}$ & 6.2 & \pm 0.2 & 6.6 & \pm 0.4 \\
\hline $\mathrm{Na}_{2} \mathrm{O}$ & 1.56 & \pm 0.08 & 2.6 & \pm 0.4 \\
\hline $\mathrm{K}_{2} \mathrm{O}$ & 0.76 & \pm 0.06 & 1.00 & \pm 0.18 \\
\hline $\mathrm{P}$ & 0.21 & \pm 0.01 & 0.22 & \pm 0.02 \\
\hline ppm & $\begin{array}{l}\text { Arith- } \\
\text { metic } \\
\text { mean }\end{array}$ & $\begin{array}{l}\text { Standard } \\
\text { deviation }\end{array}$ & $\begin{array}{l}\text { Arith- } \\
\text { metic } \\
\text { mean }\end{array}$ & $\begin{array}{l}\text { Standard } \\
\text { deviation }\end{array}$ \\
\hline $\mathrm{Ni}$ & 552 & 325 & 123 & 92 \\
\hline $\mathrm{Cu}$ & 85 & 48 & 60 & 36 \\
\hline As & 14 & 22 & 12 & 9 \\
\hline $\mathrm{Pb}$ & 48 & 18 & 44 & 19 \\
\hline $\mathrm{Zn}$ & 134 & 23 & 154 & 52 \\
\hline $\mathrm{Cr}$ & 1565 & 968 & 289 & 105 \\
\hline $\mathrm{Sr}$ & 468 & 173 & 567 & 326 \\
\hline $\mathrm{Zr}$ & 87 & 25 & 104 & 52 \\
\hline $\mathrm{Ba}$ & 690 & 214 & 770 & 280 \\
\hline
\end{tabular}

doritic plagioclase, occurs in poikilitic grains. Other major minerals are hornblende and biotite. Accessoric minerals are chlorite, sericite, zircon, carbonate, apatite, epidote and opaques. Texture is granoblastic to porphyritic, massive under the microscope and medium-grained.

In the uralite gabbro the major mineral is uralitic hornblende with sporadic remnants of pyroxene. In a few samples plagioclase with the average composition of labradorite predominates. The other major component is biotite. Accessories are chlorite, apatite, epidote, carbonate, muscovite and opaques.

The hornblende gabbro is characterized by ophitic texture. The predominating major mineral is either andesinic or bytownitic plagioclase or hornblende, which is partly uralitic. Other major minerals are biotite and chlorite. Accessories are apatite, muscovite, epidote, carbonate and opaques. Some varieties of the hornblende gabbro contain significant amounts of quartz, thus grading into a quartz diorite.

\section{Geophysical interpretation of the gravimetric data}

The average density of the Valkiajärvi gabbros is $2.94 \mathrm{gr} / \mathrm{cm}^{3}$ (42 determinations), and the corresponding value of the surrounding granite gneisses $2.73 \mathrm{gr} / \mathrm{cm}^{3}$ (12 determinations). Thus the interpretation of the gravimetric data is based on the difference value of $0.2 \mathrm{gr} / \mathrm{cm}^{3}$. According to Fig. 15, the gabbro massif has an overall dip of $65^{\circ}-70^{\circ}$ towards $\mathrm{NE}$, extending to the depth of about 300 meters. This information is most reliable in profile $\mathrm{K}$ 64.6, where the steep NE slope of the positive gravity anomally suggest the comparatively shallow depth of the massif.

The geophysical data supports the view that the two separate gabbro occurrences on Fig. 14 belong to a single body, which is covered by a gneiss saddle. This result, however, might be modified by geological data since in the area between the two gabbro bodies rocks of higher density occur: calcsilicate rocks with $2.85 \mathrm{gr} / \mathrm{cm}^{3}$ (16 determinations) and amphibolites with $2.88 \mathrm{gr} / \mathrm{cm}^{3}$ (15 determinations).

\section{Mineralizations and silicate nickel contents}

In the Mertakoski-Vehka intrusive body the major part of the $\mathrm{Ni}-\mathrm{Cu}$ deposit is bound to the ultramafic differentiates in the upper 

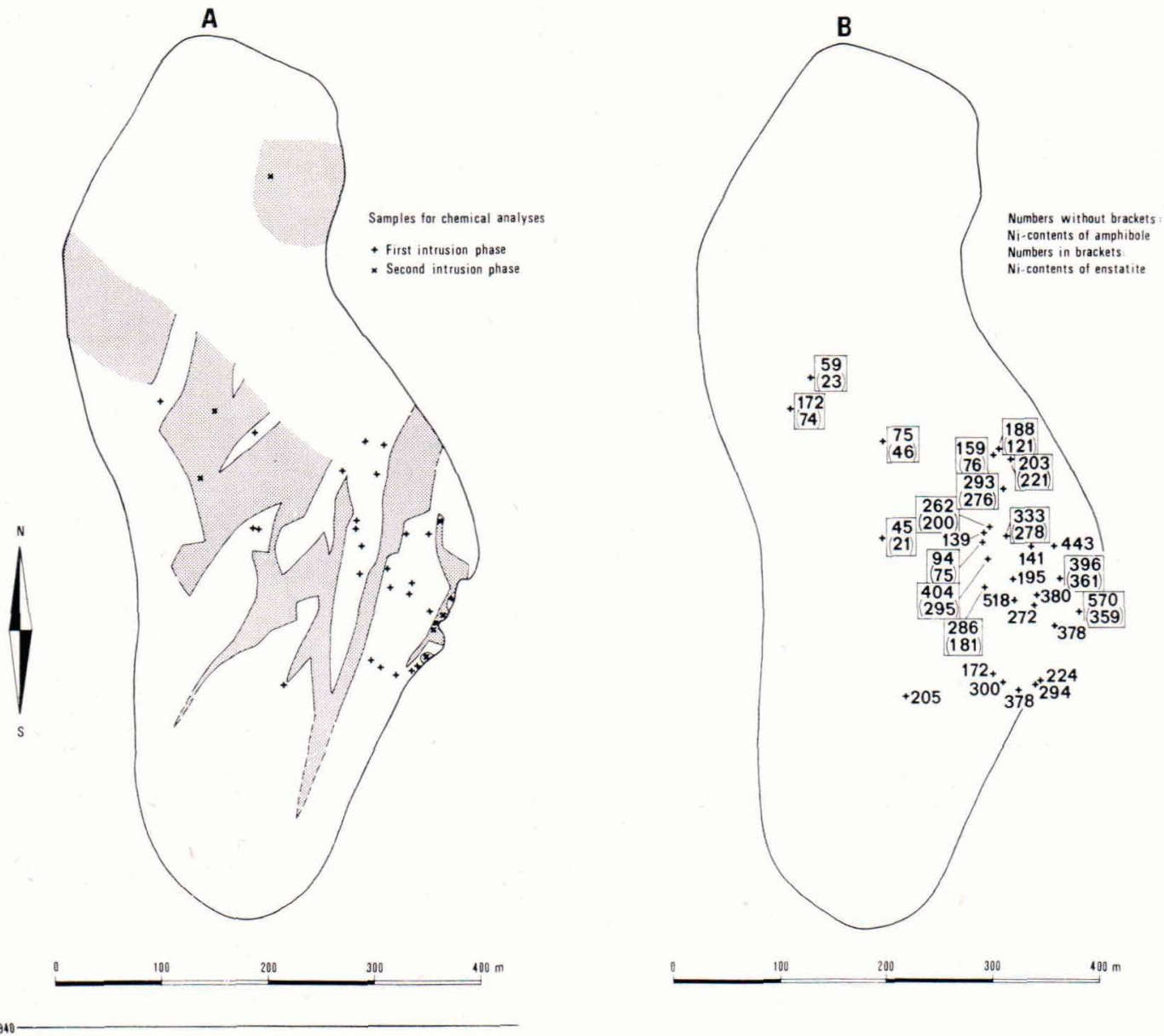

Fig. 16 A. Distribution of the first and second intrusion phase (stripled) in the Valkiajärvi gabbro. Fig. 16 B. Silicate nickel contents of the Valkiajärvi gabbro. Numbers without brackets: nickel in amphibole $(\mathrm{ppm})$. Numbers in brackets: nickel in enstatite (ppm).

part of the complex and the ore is both of the disseminated and the breccia type ( $\mathrm{Pa}-$ punen, 1970, Papunen and Koskinen, 1978). At the upper levels also the gabbros contain disseminated ore, but at lower levels mafic rocks are devoid of sulfides. The sulfide occurrences form a U-shaped flattened body, which is known in the north as Mertakoski ore body, in the lowermost center as the Välimalmio ore body and in the south as the Vehka ore body (Fig. 12). The Huuhtijärvi pipe with its mineralized perknite forms the Huuhtijärvi ore body and analogously the Jussi ore body is a separate pipe $150 \mathrm{~m}$ east of the Vehka ore body. In the Jussi ore body veins of massive sulfide ore intrude carbonate and calc-silicate rocks (Papunen, 1974).

The nickel content of the sulfide phase in the breccia and massive type of ore is rather constant, being little more than $6 \%$, with the exception of the Jussi ore body where the corresponding figure is $11 \%$ (Papunen and Koskinen, 1978). In the dis- 


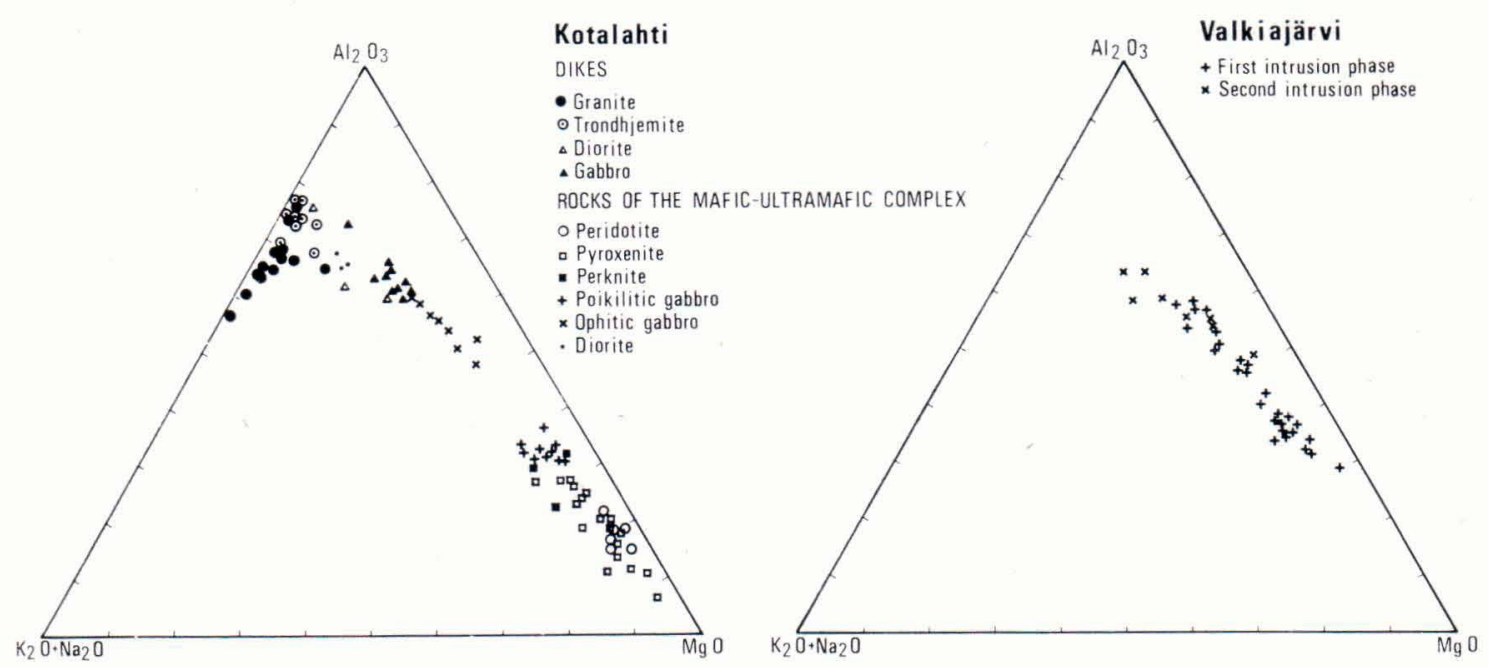

Fig. 17. The chemical composition of the Valkiajärvi gabbros compared to the $\left(\mathrm{Na}_{2} \mathrm{O}+\mathrm{K}_{2} \mathrm{O}\right)-\mathrm{Al}_{2} \mathrm{O}_{3}$ - Mg diagram of the Kotalahti intrusion by Papunen et al. (1979).

seminated type of ore the nickel content of the sulfides correlates with the magnesium content of the host rock, being in peridotites $9.8 \%$, in pyroxenites $9.2 \%$, in perknites $8.4 \%$, in gabbros $5.9 \%$ and in diorites and quartz diorites $1.4 \%$ (Papunen, 1970). The average nickel content of the sulfide phase of various rock types of the Kotalahti deposit is $6 \%$ (Häkli, 1963).

The study of silicate nickel proved to be useful in delineating mafic and ultramafic rocks favorable for the occurrence of nickel sulfide deposits (Häkli, 1971). Olivine, orthopyroxene, augite and amphibole both from the Kotalahti plutonic complex and the Valkiajärvi gabbro complex were analyzed for nickel by electron microprobe in the Geological Laboratory of the Outokumpu Oy. The results from Kotalahti are given by Papunen and Koskinen (1978). The nickel content in olivine is $1000-3000 \mathrm{ppm}$, in augite $50-400 \mathrm{ppm}$, in average $250 \mathrm{ppm}$, and in enstatite $100-850 \mathrm{ppm}$, the bulk of determinations being $100-400 \mathrm{ppm}$. The nickel content of the amphibole varies according to the rock type and the average values are $490 \mathrm{ppm}$ in peridotite, $420 \mathrm{ppm}$ in pyroxenite, $370 \mathrm{ppm}$ in perknite and 106 ppm in the ophitic hornblende gabbro.

For comparison 40 samples from the Valkiajärvi gabbro have been analyzed for the present study. Results are displayed in Fig. 16. Olivine has not been detected in the samples and augite is only sporadically met with; thus only results from enstatite and amphibole are of significance. In the uralite and pyroxene gabbros of the first intrusion phase the silicate nickel decreases from east to west in enstatite, from $361 \mathrm{ppm}$ at the eastern margin to $75 \mathrm{ppm}$ in the west. The nickel in the amphibole decreases accordingly from $570 \mathrm{ppm}$ to $46 \mathrm{ppm}$. In the ophitic hornblende gabbro of the second intrusion phase the silicate nickel is low: 21 to $74 \mathrm{ppm}$ in enstatite and 7 to $172 \mathrm{ppm}$ in amphibole. The samples contain little sulfides, the sulfur

Fig. 18. The $\mathrm{SiO}_{2}, \mathrm{TiO}_{2}, \mathrm{Al}_{2} \mathrm{O}_{2}, \mathrm{FeO}, \mathrm{MnO}, \mathrm{CaO}$, $\mathrm{Na} 2 \mathrm{O}, \mathrm{K}_{2} \mathrm{O}, \mathrm{Ni}, \mathrm{Cu}, \mathrm{S}, \mathrm{P}$ and $\mathrm{Cr}$ contents of the mafic and ultramafic plutonic rocks of Kotalahti and Valkiajärvi plotted versus $\mathrm{MgO}$ content. 

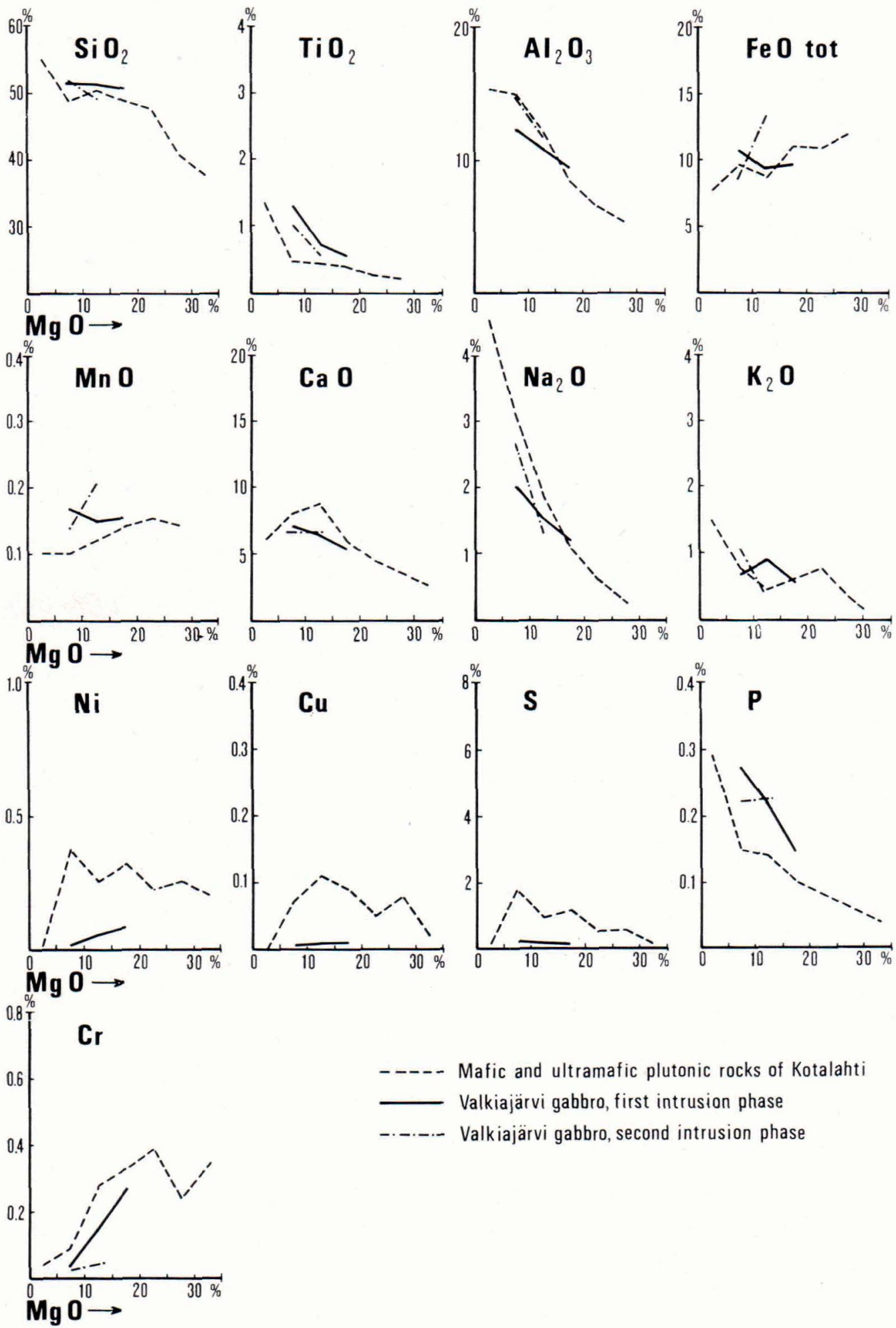

- --- Mafic and ultramafic plutonic rocks of Kotalahti

— Valkiajärvi gabbro, first intrusion phase

-...-. Valkiajärvi gabbro, second intrusion phase 
content being $0.02 \%$ to $0.5 \%$, and on average, $0.16 \%$. The nickel content of the sulfide phase of the Valkiajärvi gabbro is accordingly low, $191 \mathrm{ppm}$ on average, in the 40 samples.

The distribution of the silicate nickel in the first phase of the Valkiajärvi gabbro could be explained in two ways. Either the nickel is enriched towards the eastern margin of the body or the western part of the gabbro is depleted in nickel. Since the iron and magnesium content of the mafic silicates has not been determined, no definite choice can be made between the two alternatives. The whole rock $\mathrm{MgO}$ content correlates with the silicate nickel and $\mathrm{MgO}$ is increasing towards the eastern margin of the intrusive body indicating magmatic differentiation. On the other hand the very low nickel content of the western margin of the massif awakes the suspicion that nickel might have been extracted at the proximity of the Kotalahti deposit.

On the $\left(\mathrm{Na}_{2} \mathrm{O}+\mathrm{K}_{2} \mathrm{O}\right)-\mathrm{Al}_{2} \mathrm{O}_{3}-\mathrm{MgO}$ diagram the Valkiajärvi gabbros are comparable to the chemical composition of the mafic and ultramafic plutonic rocks of Kotalahti as given by Papunen et al. (1979), although the magmatic differentiation of the exposed part of the Valkiajärvi massif is less developed (Fig. 17). Part of the uralite gabbros and pyroxene gabbros plot into the field of the poikilitic gabbro of Kotalahti. These gabbros show in the Valkiajärvi gabbro complex transition into the field of the hornblende gabbros, which plot into the field of the ophitic gabbros and dike gabbros of Kotalahti. The $\mathrm{SiO}_{2} \mathrm{TiO}_{2} \mathrm{Al}_{2} \mathrm{O}_{3}, \mathrm{FeO}, \mathrm{MnO}, \mathrm{CaO}, \mathrm{Na}_{2} \mathrm{O}$, $\mathrm{K}_{2} \mathrm{O}, \mathrm{Ni}, \mathrm{Cu}, \mathrm{S}, \mathrm{P}$ and $\mathrm{Cr}$ contents of Kotalahti (A Häkli, personal communication) and Valkiajärvi are compared at increasing $\mathrm{MgO}$ contents on Fig. 18. There is a significant difference in the $\mathrm{Ni}, \mathrm{Cu}, \mathrm{S}, \mathrm{TiO}_{2}$ and $\mathrm{P}$ contents. The higher $\mathrm{Ni}, \mathrm{Cu}$ and $\mathrm{S}$ contents in Kotalahti can be explained by the mineralization process.

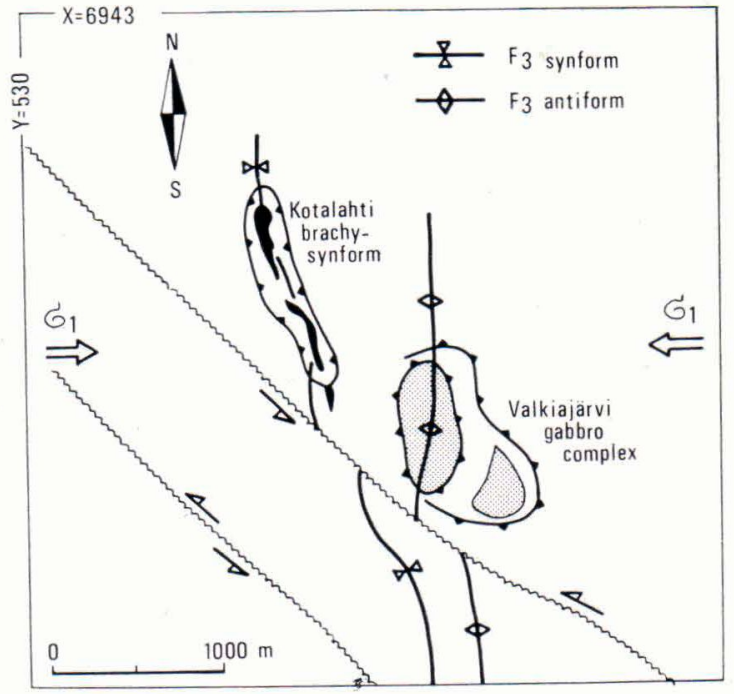

Fig. 19. Dynamic interpretation of the third and fourth deformation phases governing the intrusion tectonics of the mafic and ultramafic, plutonic rocks of the Kotalahti area.

\section{Conclusions}

The mafic and ultramafic plutonic rocks intruded rocks of Archean age during a Proterozoic event about $1900 \mathrm{Ma}$ ago. According to the result of the structural analysis, this event comprises the deformation phases $\mathrm{F}_{3}$ and $\mathrm{F}_{4}$. These two phases developed probably as a response of the crust to an approximately east-west oriented compression, which caused north-south trending synforms and antiforms at the first stage and a NW-SE striking subvertical ductile shear zone with left lateral flow at the second stage (Fig. 19). The shear zone is probably the upper part of a deep-seated fault, which might have been active for a long time before the $F_{3}$ phase. This fault was the weakness zone, along which the material ascended from the upper mantle. The Valkiajärvi gabbro intruded the Valkeinen brachyantiform during the $\mathrm{F}_{3}$ folding and developed into the shape of a dome. The suitable conduit for the Kotalahti mafic and ultramafic plutonic rocks was the hinge zone of an $F_{3}$ synform, 
which in a later event was refolded into the Kotalahti brachysynform. The differentiated rocks became mixed up during the intrusion process and this caused the reversed position of the ultramafic differentiates in the Kotalahti deposit. Further complication is caused by the multiple nature of the intrusions. A younger intrusion phase composed of the ophitic gabbro is clearly recognizable in the Valkiajärvi gabbro complex. In the Kotalahti deposit several swarms of dikes, the breccia type of ore and veins of massive sulfide ore are indicators of a multiple intrusion process.

One of the conclusions of this paper is of regional significance. The detailed structural work combined with mineral-age determinations disproves the Proterozoic age of part of the Savo schists. The epicontinental group around the Valkeinen brachyantiform and corresponding rocks in the Kuopio domes cannot be correlated with the Jatulian group but represent an Archean rock association.

\section{References}

Ehlers, C. (1978) Gravity tectonics and folding around a basic volcanic centre in the Kumlinge area, SW Finland. Geol. Surv. Finland, Bull. 295, 43 pp.

Gaál, G. (1970) Raportti Kotalahden ympäristön aluetutkimuksesta. Unpubl. manuscript, Outokumpu Oy, Exploration.

- (1972) Tectonic control of some Ni-Cu-deposits in Finland. 24th IGC, Section 4, 215-224.

- and Rauhamäki, E. (1971) Petrological and structural analysis of the Haukivesi area between Varkaus and Savonlinna, Finland. Bull. Geol. Soc. Finland 43, 265-337.

- and Suokonautio, V. (1973) An automatic data processing system for exploration mapping in Precambrian terrain: GEOKU. Geol. Surv. Finland, Bull. 266, 26 pp.

- Koistinen, E., Lehtonen, M. and Tontti, M. (1978) Deposit modelling of a nickel belt in Finland. Mathematical Geology 10, 543-554.
Acknowledgements - The author would like to express his gratitude to the management of the Outokumpu Oy, Exploration, for the positive attitude towards this research and for the permission to publish this paper. Special thanks are due for the support given by the Kotalahti mine, in the first place to the chief of the geological staff, Juhani Koskinen, M.Sc. who helped with many advises during all stages of the work. For mineral age determinations the author in indebted to Dr. Olavi Kouvo of the Geological Survey of Finland and Dr. Frank J. Fitch of FM Consultants Itd, Kent, England. Nickel silicate analyses and X-ray fluorescence analyses were arranged by Dr. Aulis Häkli of the Outokumpu Oy, who is also remembered for many discussions on the subject. Dipl.eng. Ensio Lakanen helped with the geophysical interpretation of the gravimetric data of the Kotalahti area. The author also expresses his gratitude to Tapio Karppanen, M.Sc., Dr. Jyrki Parkkinen and Kimmo Niskanen for the exchange of ideas. Constructive criticism of the paper by Professor Heikki Papunen, Dr. Aulis Häkli, Dr. Olavi Kouvo and Tapio Koistinen, M.Sc. is acknowledged. For the drafting, thanks are due to Mrs. Riitta Virtanen of the Department of Geology, University of Helsinki.

Haapala, P. (1969) Fennoscandian nickel deposits. Econ. Geol. Monograph 4, 262-275.

Häkli, A. (1963) Distribution of nickel between the silicate and sulphide phases in some basic intrusions in Finland. Bull. Comm. géol. Finlande 209, $54 \mathrm{pp}$.

Häkli, T. A. (1971) Silicate nickel and its application to the exploration of nickel ores. Bull. Geol. Soc. Finland 43, 247-263.

Härme, M. (1959) Examples of the granitization of gneisses. Bull. Comm. géol. Finlande 184, $41-58$.

Irvine, T. N. and Baragar, W. R. A. (1971) A guide to the chemical classification of the common volcanic rocks. Can. J. Earth Sciences 8, 523548.

Isokangas, P. (1978) Finland. In Mineral deposits of Europe, vol. 1: Northwest Europe. The Institution of Mining and Metallurgy and The Mineralogical Society, London, 39-92.

Jaffey, A. H., Flynn, K. F., Glendenin, L. E., Bentley, W. C. and Essling, A. M. (1971) Pre- 
cision measurement of half-lives and specific activities of $235 \mathrm{U}$ and $238 \mathrm{U}$. Physical Review C, 4 (5), 1889-1893.

Kahma, A. (1973) The main metallogenic features in Finland. Geol. Surv. Finland, Bull. 265, 29 pp.

Kouvo, O. and Tilton, G. R. (1966) Mineral ages from the Finnish Precambrian. Jour. Geol. 74, $421-442$.

Myers, J. S. (1978) Formation of banded gneisses by determination of igneous rocks. Precambrian Research 6, 43-64.

Niskanen, K. (1980) Kotalahden alueen epikontinentaaliryhmän stratigrafia, petrografia ja geokemia. Unpubl. M. Sc. thesis, Univ. Helsinki, Dept. Geology.

Papunen, H. (1970) Sulfide mineralogy of the Kotalahti and Hitura nickel-copper ores, Finland. Annales Academiae Scientiarium Fennicae, Ser. A, 109, $74 \mathrm{pp}$.

- and Koskinen, J. (1978) Geology of the Kotalahti $\mathrm{Ni}-\mathrm{Cu}$ ore. In Metallogeny of the Baltic Shield, Helsinki Symposium 1978, The Academy of Finland, Excursion guide, 69-82.

- , Häkli, T. A. and Idman, H. (1979) Geological, geochemical and mineralogical features of sulfide-bearing ultramafic rocks in Finland. Canadian Mineralogist 17, 217-232.

Parkkinen, J. (1974) Leppävirran aluetutkimus 1968-1972. Unpubl. manuscript, Outokumpu Oy, Exploration.

- (1975) Deformation analysis of a Precambrian mafic intrusive: Haukivesi area, Finland. Geol. Surv. Finland, Bull. 278, 61 pp.

Preston, J. (1954) The geology of the Pre-Cambrian rocks of the Kuopio district. Annales
Academiae Scientiarium Fennicae, Ser. A, 111 pp.

Ramsay, J. G. and Graham, R. H. (1970) Strain variation in shear belts. Canadian J. Earth Sci. $77,786-813$.

Simonen, A. (1971) Das finnische Grundgebirge. Geol. Rundschau 60, 1406-1421.

Talvitie, J. (1971) Seismotectonics of the Kuopio region, Finland. Bull. Comm. géol. Finlande 248, $41 \mathrm{pp}$.

- (1975) Fractures, dynamic model and $\mathrm{Ni}-\mathrm{Cu}$ mineralized basic intrusives in Central Finland. Geol. Surv. Finland, Report of Investigation $10,3-12$.

Tontti, M., Koistinen, E. and Lehtonen, M. K. A. (1979) Kotalahden nikkelivyöhykkeen monimuuttuja-analyysi. Abstract: A multivariate analysis of the Kotalahti Nickel Belt. Geol. Surv. Finland, Report of Investigation 36, $34 \mathrm{pp}$.

Tuominen, H., Aarnisalo, J. and Söderholm, B. (1973) Tectonic patterns in the Central Baltic Shield. Bull. Geol. Soc. Finland 45, 205-217.

Wetherill, G. W. (1956) Discordant uranium-lead ages, I. Transactions, American Geophysical Union, 37 (3), 320-326.

-, Kouvo, O., Tilton, G. R. and Gast, P. W. (1962) Age measurements on rocks from the Finnish Precambrian. Jour. Geol. 70, 74-88.

Wilkman, W. W. (1938) Suomen geologinen yleiskartta, Lehti C 3, Kuopio, Kivilajikartan selitys. Suomen geologinen toimikunta, $171 \mathrm{pp}$.

York, D. (1966) Least-squares fitting of a straight line. Canadian Journal of Physics, 44, 10791086.

Manuscript received, February 28, 1980 